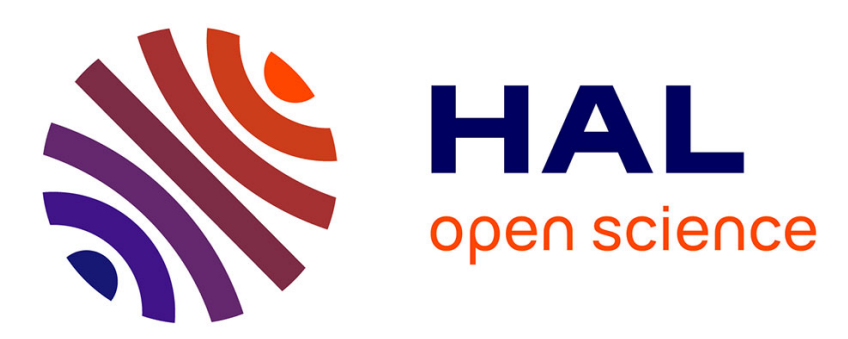

\title{
Molecular dynamics simulations of peptides on calcite surface
}

\author{
Mingjun Yang, Mark Rodger, John Harding, Susan S.L. Stipp
}

\section{To cite this version:}

Mingjun Yang, Mark Rodger, John Harding, Susan S.L. Stipp. Molecular dynamics simulations of peptides on calcite surface. Molecular Simulation, 2009, 35 (07), pp.547-553. 10.1080/08927020802627399 . hal-00515068

\section{HAL Id: hal-00515068 \\ https://hal.science/hal-00515068}

Submitted on 4 Sep 2010

HAL is a multi-disciplinary open access archive for the deposit and dissemination of scientific research documents, whether they are published or not. The documents may come from teaching and research institutions in France or abroad, or from public or private research centers.
L'archive ouverte pluridisciplinaire HAL, est destinée au dépôt et à la diffusion de documents scientifiques de niveau recherche, publiés ou non, émanant des établissements d'enseignement et de recherche français ou étrangers, des laboratoires publics ou privés. 


\section{Molecular Simulation}

Journal of

Experimental Nanoscience

- Taylor \& Francis

Taglor \& Francis Group

\section{Molecular dynamics simulations of peptides on calcite surface}

\begin{tabular}{|r|l|}
\hline Journal: & Molecular Simulation/Journal of Experimental Nanoscience \\
\hline Manuscript ID: & GMOS-2008-0222.R1 \\
\hline Journal: & Molecular Simulation \\
\hline Date Submitted by the \\
Author: & 09-Nov-2008 \\
\hline Complete List of Authors: & $\begin{array}{l}\text { Yang, Mingjun; University of Copenhagen, Nano-Science Center } \\
\text { Rodger, Mark; University of Warwick, Department of Chemistry } \\
\text { Harding, John; University of Sheffield, Department of Engineering } \\
\text { Materials } \\
\text { Stipp, Susan; University of Copenhagen, Nano-Science Center }\end{array}$ \\
\hline Keywords: & molecular simulation, peptides, biomineralization, calcite, surface \\
\hline
\end{tabular}

\section{SCHOLARONE \\ Manuscripts}


1

2

3

4

5

6

7

8

9

10

11

12

13

14

\title{
Molecular dynamics simulations of peptides on calcite surface
}

\author{
Mingjun Yang ${ }^{\mathrm{a}, *}, \underline{\text { P. Mark Rodger }}{ }_{2}^{\mathrm{b}}$ John H. Harding $^{\mathrm{c}}$ and S. L. S. Stipp ${ }_{-}^{\mathrm{a}}$ \\ ${ }^{a}$ NanoScience Centre, University of Copenhagen, Copenhagen, Denmark \\ ${ }^{\mathrm{b}}$ Department of Chemistry, University of Warwick, United Kingdom \\ ${ }^{\mathrm{c}}$ Department of Engineering Materials, University of Sheffield, United Kingdom
}

Deleted: and

Deleted:

\section{Abstract}

A series of Molecular Dynamics (MD) simulations has been carried out to investigate the interaction between peptides and a calcite $(10 \overline{1} 4)$ _surface _in water. A 16-amino acid and a 17-amino acid peptide have been built and three different configurations for each peptide are used as starting configurations. The dynamic behaviour of these peptides has been investigated by calculating their radii of gyration and distribution of dihedral angles. For comparison, the simulations of peptides in vacuum and water have also been carried out. The simulations indicate that these peptides generally have strong interactions with the calcite surface and the peptides changed their configuration to favour this interfacial interaction. Continuum electrostatic calculations based on the Poisson-Boltzmann equation (PBE) have also confirmed strong electrostatic interactions between peptides and the calcite surface. The results suggest that peptides can control calcite crystallisation and that strong electrostatic interactions between peptides and calcite surfaces dominate the interfacial interactions.

\footnotetext{
"Corresponding author. Tel: +45 353201 56. Email: mjyang@ nano.ku.dk.
}

Deleted: D

Formatted: Font: Times New Roman, Lowered by $5 \mathrm{pt}$

Deleted: (1 0.4$)$

Deleted: Two peptides $\left(\mathrm{R}_{2} \mathrm{E}_{2} \mathrm{~W}_{2} \mathrm{D}_{2}-16\right.$ and $\mathrm{R}_{2} \mathrm{E}_{2} \mathrm{~W}_{2} \mathrm{D}_{2} \mathrm{P}-17$ )

Deleted:

Deleted: behavior

Deleted: us

Deleted: e

\section{Deleted: e}

Deleted: s

Deleted: II 
Keywords: molecular simulation; peptide; biomineralization; calcite; surface 
1

2

3

4

5

6

7

8

9

\section{Introduction}

Knowledge of the interactions between proteins and calcite surfaces is a key to understanding biomineralization, Progress in experiment has greatly improved our understanding of the role of peptides and proteins in the mechanism of biomineralization and shows that the structure of these biomolecules is very important in controlling crystal growth. A study on mollusk shell proteins AP7 and AP24 indicates that some structural features of these proteins will greatly influence their kinetic behavior in mineralization [1]. Again the control of crystal growth by proteins is demonstrated in the formation of eggshell Recently, ovocleidin- 17 has been identified as the major protein of calcified eggshell, and the three-dimensional structure of this protein is believed to closely relate to its functionality in the biomineralization process [2] Ajikumar and colleagues have used charged peptides to mimic the function of eggshell proteins and the results show that these peptides were able to facilitate the nucleation and growth of polycrystalline calcium carbonate[3], Metzler and colleagues used X-ray absorption near edge spectroscopy (XANES) to study the electronic structure of crystalline calcium carbonate and peptides at the surface, and hence the mutual effects of calcite on peptides and peptides on calcite during biomineralization [4], A study on mollusk shell proteins AP7 and AP24 indicates that some structural features have an important influence in their kinetic behavior during mineralization, which suggests protein structure plays a very important role in controlling biomineralization [1],

However, current understanding of the interaction between biomolecules and minerals during biomineralisation is far from complete. Here, computer simulations can be an
Deleted: Understanding about

Deleted: mineralisation Deleted: controlled by organisms

\begin{tabular}{|c|}
\hline Deleted: mineralisation \\
\hline Deleted: [1] \\
\hline Field Code Changed \\
\hline Field Code Changed \\
\hline Deleted: [2] \\
\hline Deleted: demonstrated \\
\hline Deleted: interaction \\
\hline Deleted: mineralisation \\
\hline Field Code Changed \\
\hline Deleted: [3] \\
\hline Deleted: mineralisation \\
\hline Field Code Changed \\
\hline Deleted: [4] \\
\hline $\begin{array}{l}\text { Deleted: Experimental evidence has } \\
\text { greatly contributed to our understanding } \\
\text { about the biomineralisation in the } \\
\text { presence of peptides and proteins, and } \\
\text { shows that the structures of these } \\
\text { biomolecules plays a key role in } \\
\text { controlling crystal growth, but complete } \\
\text { description of the mechanism is lacking. } \\
\text { On the other hand, the rapid-development } \\
\text { computer simulations provide an effective } \\
\text { tool to explore possible mechanisms of } \\
\text { biomineralisation. Computer simulations } \\
\text { can be used to obtain atomistic details } \\
\text { about the chemical environment at the } \\
\text { interface between biomolecules and } \\
\text { mineral surfaces; hence we can gain a } \\
\text { more complete understanding of the } \\
\text { controls on biomineralisation processes. II }\end{array}$ \\
\hline
\end{tabular}


effective tool to explore the mechanism of biomineralisation. Computer simulations

can be used to obtain the atomistic details at the interface between biomolecules and

mineral surfaces; hence we can have a better understanding of the mechanisms by

which the biomineralisation is controlled.

Potential-based molecular dynamics (MD) simulations are increasingly used in the

Deleted: to study the study of calcite biomineralization. Normally, a set of potentials is only used for

Deleted: mineralisation Deleted: of calcite specific type of molecule models, and potentials used in simulations of macromolecules are usually different from those for crystals. In the case of biomineralization, potentials for biomolecules, mineral, solutes and their cross-terms are needed. The competitive adsorption among organic molecules with different functional groups to calcite surfaces has been examined with a combination of potentials [5]. Freeman et al. have systematically developed a method to generate a set of potentials for modelling biomineralization [6]. The potentials have been applied to simulate the interaction between polysaccharides and calcite, and facilitate the simulations of biomolecules and inorganic surfaces [7]. Peptides are highly charged molecules so the electrostatic interactions between peptides and mineral surfaces dominate the interfacial interactions.

The Poisson-Boltzmann equation (PBE) has been proposed as an effective continuum model to evaluate the electrostatic properties [8]. This model uses implicit solvent and can determine the contribution of electrostatic to the forces and energies of a molecular system.

In this study, we used MD simulations to simulate the dynamical behaviour of 
A 16-amino acid peptide (Arg Arg Glu Glu Trp Trp Asp Asp Arg Arg Glu Glu Trp Trp

Deleted: Two

peptides on calcite. The adsorption of peptides on calcite $(10 \overline{1} 4)$ has been calculated

and electrostatic interactions between the peptides and calcite surface have been examined with PBE continuum electrostatic calculations.

\section{Methods}

Asp Asp) and a 17-amino acid peptide (Arg Arg Glu Glu Trp Trp Asp Asp Pro Arg Arg Glu Glu Trp Trp Asp Asp) were built with the Amber 9 program [9]. These two peptides have been reported to facilitate the nucleation, growth and aggregation of calcite crystal [3]. A peptide can have a variety of configurations; each configuration Deleted: s may have a different influence on calcite crystal growth. Therefore, for each peptide simulated, we generated three configurations, alpha-helix, extended and beta-turn.

The configurations of the two peptides are thus denoted as $\mathrm{PI}(\mathrm{A}), \mathrm{PI}(\mathrm{B}), \mathrm{PI}(\mathrm{C})$ and PII(A), PII(B), PII(C). The three-dimensional structures are presented in Figure 1.

Calcite has a rhombohedral crystal structure, space group $R \overline{3 c}$ where $a=b=4.988 \AA$, $c=17.061 \AA, \alpha=\beta=90^{\circ}$ and $\gamma=120^{\circ}$ [10]. The calcite (10 $\left.\overline{1} 4\right)$ surface shown in Figure 2 was built with Materials Studio 4.0 [11].

In the modeling, we put water and a peptide molecule on a calcite surface as shown in

Fig. 3. Because all the peptides under study were negatively charged with $-4 e$, two calcium ions were added to each peptide in order to neutralize the system. The temperature was $300 \mathrm{~K}$ and a three-dimensional periodic boundary was used. All the MD simulations were carried out using the DL_POLY 2.18 code[12] with a set of 
force fields designed for use at bio-inorganic interfaces [6]. Full details about the force fields between the organic molecule and the mineral are given in that reference.

The interaction potentials used for $\mathrm{CaCO}_{3}$ were those derived by Pavese et al. [13] for Formatted: Font: Italic modeling a range of properties of calcite and aragonite crystals. The potentials for peptides were obtained from the ff03 force field in AMBER; the flexible TIP3P potential was used for water [14].

The coordinates of both peptides and the calcite surface obtained from the final configuration of MD simulations were used as input for PBE calculations. After taking away all the water molecules, PBE calculations were performed with the APBS Deleted: By Deleted: implemented program [8]. In the calculation, the solute intramolecular interactions were computed by the usual molecular mechanics mothods, while the solute-solvent and solventsolvent interactions were computed by a mean-field approximation through the use of PB electrostatic theory. The dielectric constant for water was set to 80.0 , and 8.0 for the calcite surface and peptides.

\section{Results and Discussion}

\subsection{Peptides in vacuum}

The MD simulations of peptides in vacuum were carried out at $300 \mathrm{~K}$ for $2 \mathrm{~ns}$. From Fig. 4 we can see that after the initial equilibration period, the configurations of the peptides became stable, as characterized by their radii of gyration. The potential energy underwent variance during the simulations. The results show that the potential energy of a peptide in vacuum is closely linked to its specific configuration.

Deleted: A

Deleted: which is 
Configurations with coiled structure (smaller gyration radius) are energetically

favourable since molecules with this kind of configuration are able to interact with themselves so their potential energy is lowered by these intramolecular interactions.

PI(A ) and PII(B) have the largest gyration radius in all of the PI and PII

configurations during the simulations, and as a result, their potential energies are the

largest. The change of peptide configuration as indicated from the gyration radius will induces a change of potential energy of the peptide. For example, the gyration radius of PIL(A) decreased sharply (about $10 \%$ ) at $\mathrm{t}=1300 \mathrm{ps}$ and accordingly, its potential energy increased from around -2100 to $-2400 \mathrm{~kJ} / \mathrm{mol}$.

\subsection{Peptides in water}

The simulations of peptides in water were carried out at $300 \mathrm{~K}$ for $2 \mathrm{~ns}$. The potential energy and gyration radius for the peptide molecule were examined for each simulation, and results are shown in Fig. 5. The solvation of peptides by water molecules can greatly stabilize peptide molecules. There is no obvious difference in potential energy between the peptides. Their larger gyration radius in water indicates Deleted: for any of that they tend to maintain an extended structure such as PI (B) and PII (B). The difference in dynamic behaviour of peptides with and without water molecules, as seen from the gyration radius calculations, implies that the presence of water molecules has great influence on the functionality of peptides during biomineralization.

\section{Deleted: exis}

Deleted: $t$

Deleted: an important

Deleted: mineralisation

\subsection{Peptides on calcite surfaces in water}


These simulations were used to simulate adsorption of peptides on the calcite surface.

To make sure that the adsorption of peptides onto the calcite surface is that for a low energy (if possible the equilibrium) configuration, the following procedure was used to build the system. First, the peptide was put about $4 \AA$ away from the surface and

the MD simulation ran for $2.5 \mathrm{~ns}$, to allow adsorption to be complete. Second, water molecules were added to the system and a series of stepwise MD simulations were used to relax the system. After the system has equilibrated, the potential energy and the radius of gyration of the peptide could be obtained from production simulations of $2 \mathrm{~ns}$, and results are shown in Fig. 6. The results suggest that although there are differences in the gyration radius, the variability of potential energy among the Deleted: it Deleted: reached Deleted: ium

peptides is insignificant. The adsorption energy could be obtained by comparing the potential energy of the system before and after adsorption using the method described by Yang et al. [7]. The results are shown in Table 1. Low negative adsorption energy means strong adsorption between the peptide and the surface.

The peptides with the beta-turn configuration have the strongest adsorption (adsorption energies: -204.4 kJ/mol for PI (C), and -136.8 for PII (C)); those of alphahelix configuration have the weakest adsorption, and those of extended configuration have adsorption energies between those of the beta-turn and alpha-helix configurations. The dependence of adsorption energy on peptide configurations indicates that the configuration of peptides plays a key role in biomineralization Deleted: mineralisation controlled by peptides or proteins. The results agree well with the experiments, which showed that peptides with specific configurations can facilitate calcite crystal growth [3]. 
1

2

3

4

5

6

7

8

9

10

11

12

13

14

15

16

17

18

19

20

21

\subsection{Changes in dihedral angles of the peptides}

The gyration radius of a peptide can not display all the information about a peptide configuration. Therefore, the dihedral angles of the peptides have been calculated to indicate the change in configuration with more detail. For each residue unit, three dihedral angles can be defined as in Figure 7.

The distribution of each type of dihedral angle could be obtained from the trajectory of the MD simulations. For example, the distributions of all dihedral angles for PI(A) during the former simulations are shown in Fig. 8 .

During the simulations, the dihedral angle "omega" hardly changed from around $180^{\circ}$, which agrees with the expected chemical structure. The figures clearly show that the change of peptide configuration can be reflected by the change in the dihedral angles "phi" and "psi". For simulation of PI (A) in water, the distribution of the dihedral angle "phi" has a major peak around $290^{\circ}$, and a small peak around $230^{\circ}$, while the distribution of the dihedral angle "psi" has a major peak around $340^{\circ}$, and a small peak around $230^{\circ}$. The distribution of these dihedral angles shows that peptides can keep their configuration in water without significant changes. From simulations of peptides on calcite surface, we can see some new peaks and slight shifts of previous peaks. The "phi" type of dihedral angle has two new distribution peaks around $80^{\circ}$ and $170^{\circ}$, while "psi" has peaks around $70^{\circ}$ and $160^{\circ}$. The difference in distribution of dihedral angles shows the alteration of configuration of peptides after they interact with the calcite surface. 


\subsection{Electrostatic potential isosurfaces}

From the MD simulations, we are able to investigate the molecular system $\underline{\underline{n}}$

Deleted: at atomistic detail. It is still instructive to plot the potential isosurfaces of peptide and calcite with the $\mathrm{PBE}$ calculations. The electrostatic potential isosurfaces represent points of electrostatic potential within a volume of space. The results from PBE calculations with the APBS program are shown in Figure 9.

From the isosurfaces, we can see that the dominating electrostatic interaction is a key factor in peptide interactions with calcite. Two types of strong binding can be identified: 1) interactions between carbonate groups of the calcite surface and amino groups of the peptides; and 2) interactions between calcium ions in calcite and carboxyl groups of peptides.

\section{Conclusions}

Simulations of two kinds of peptides on the calcite $(10 \overline{1} 4)$ surface in water were used to investigate the interaction between peptides and this calcite surface. The results indicate that the specific configuration of peptides plays an important role in their adsorption. The calculated adsorption energies show that beta-turn configuration peptides have the strongest interaction with the calcite surface, extended configurations have less strong interactions, and alpha-helix configurations have the least interaction. From the continuum electrostatic calculations with PBE, two types of strong interaction have been identified: 1) interactions between carbonate groups of the calcite surface and amino groups of the peptides; and 2) interactions between
Formatted: Font: Times New Roman, Lowered by 5 pt

Deleted: e 
calcium ions of the calcite surface and carboxyl groups of peptides. This helps to

explain the biological control in biomineralization,

\section{Acknowledgements}

M.Y. and J.H.H. acknowledge funding from EPSRC under Grant No GR/S80103/01

and M.Y. and S.L.S.S. acknowledge funding from Maersk Olie og Gas AS Computer resources were provided by the Danish Centre for Scientific Computing (DCSC) and the MOTT facility (EPSRC Grant GR/S84415/01), run by the STFC e-Science Centre.

We also thank Colin L. Freeman (University of Sheffield, UK) for helpful discussions.

\section{References}

[1] S. Collino, and J.S. Evans, Structural features that distinguish kinetically distinct biomineralization polypeptides, Biomacromolecules. 5 (2007), pp.1686-1694.

[2] J.P. Reyes-Grajeda, A. Moreno, and A. Romero, Crystal structure of ovocleidin-17, a major protein of the calcified gallus gallus eggshell implications in the calcite mineral growth pattern, Journal of Biological Chemistry. 39 (2004), pp.40876-40881.

[3] P.K. Ajikumar, S. Vivekanandan, R. Lakshminarayanan, S.D.S. Jois, R.M.

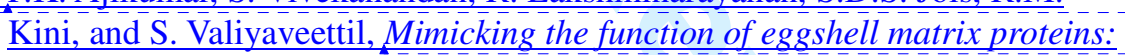
The role of multiplets of charged amino acid residues and self-assembly of peptides in biomineralization Angewandte Chemie-International Edition. 34 (2005), pp.5476-5479.

[4] R.A. Metzler, I.W. Kim, K. Delak, J.S. Evans, D. Zhou, E. Beniash, F. Wilt, M. +

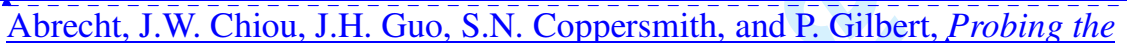
organic-mineral interface at the molecular level in model biominerals, Langmuir. 6 (2008), pp.2680-2687.

[5] D.M. Duffy, and J.H. Harding, Simulation of organic monolayers as templates for the nucleation of calcite crystals, Langmuir. 18 (2004), pp.7630-7636.

[6] C.L. Freeman, J.H. Harding, D.J. Cooke, J.A. Elliott, J.S. Lardge, and D.M. Duffy, New forcefields for modeling biomineralization processes, Journal of Physical Chemistry C. 32 (2007), pp.11943-11951.

[7] M. Yang, S.L.S. Stipp, and J. Harding, Biological control on calcite crystallization by polysaccharides, Crystal Growth \& Design. (2008).

[8] N.A. Baker, D. Sept, S. Joseph, M.J. Holst, and J.A. McCammon, Electrostatics of nanosystems: Application to microtubules and the ribosome, Proceedings of the National Academy of Sciences of the United States of America. 18 (2001), pp.10037-10041.

\begin{tabular}{|c|c|}
\hline Deleted: $\min$ & \\
\hline $\begin{array}{l}\text { Deleted: suc } \\
\text { eggshells }\end{array}$ & on of \\
\hline Deleted: We & \\
\hline Deleted: c & \\
\hline Deleted: er & \\
\hline $\begin{array}{l}\text { Formatted: } \\
\text { Roman No9 L, } \\
\text { No9 L }\end{array}$ & $\begin{array}{l}\text { imbus } \\
\text { Roman }\end{array}$ \\
\hline $\begin{array}{l}\text { Formatted: } \\
\text { Roman No9 L }\end{array}$ & ibus \\
\hline $\begin{array}{l}\text { Formatted: } \\
\text { Roman No9 L, }\end{array}$ & tbus \\
\hline $\begin{array}{l}\text { Formatted: } \\
\text { Roman No9 L }\end{array}$ & ibus \\
\hline $\begin{array}{l}\text { Formatted: } \\
\text { Roman No9 L, } \\
\text { No9 L }\end{array}$ & $\begin{array}{l}\text { imbus } \\
\text { Roman }\end{array}$ \\
\hline $\begin{array}{l}\text { Formatted: } \\
\text { Roman No9 L }\end{array}$ & ibus \\
\hline $\begin{array}{l}\text { Formatted: } \\
\text { Roman No9 L, }\end{array}$ & bus \\
\hline $\begin{array}{l}\text { Formatted: } \\
\text { Roman No9 L }\end{array}$ & bus \\
\hline Formatted & $\ldots[1]$ \\
\hline Formatted & $\ldots[2]$ \\
\hline Formatted & $\ldots$ [3] \\
\hline Formatted & $\ldots[4]$ \\
\hline Formatted & $\ldots[5]$ \\
\hline Formatted & $\ldots[6]$ \\
\hline Formatted & $\ldots[7]$ \\
\hline Formatted & $\ldots[8]$ \\
\hline Formatted & $\ldots[9]$ \\
\hline Formatted & $\ldots[10]$ \\
\hline Formatted & $\ldots[11]$ \\
\hline Formatted & $\ldots[12]$ \\
\hline Formatted & $\ldots[13]$ \\
\hline Formatted & $\ldots[14]$ \\
\hline Formatted & $\ldots[15]$ \\
\hline Formatted & $\ldots[16]$ \\
\hline Formatted & $\ldots[17]$ \\
\hline Formatted & $\ldots[18]$ \\
\hline Formatted & ... [19] \\
\hline Formatted & $\ldots[20]$ \\
\hline Formatted & $\ldots[21]$ \\
\hline Formatted & $\ldots[22]$ \\
\hline Formatted & $\ldots[23]$ \\
\hline Formatted & $\ldots[24]$ \\
\hline Formatted & $\ldots[25]$ \\
\hline
\end{tabular}


[9] D.A. Case, T.A. Darden, I. T.E. Cheatham, C.L. Slimmerling, J. Wang, R.E. Duke, R. Luo, K.M. Merz, D.A. Pearlman, M. Crowley, R.C. Walker, W. Zhang, B. Wang, S. Hayik, A. Roitberg, G. Seabra, K.F. Wong, F. Paesani, X. Wu, S. Brozell, V. Tsui, H. Gohlke, L. Yang, C. Tan, J. Mongan, V. Hornak, G. Cui, P. Beroza, D.H. Mathews, C. Schafmeister, W.S. Ross, and P.A. Kollman Amber 9 , University of California: San Francisco, 2006.

[10] S.A. Markgraf, and R.J. Reeder, High-temperature structure refinements of calcite and magnesite, American Mineralogist. $5-6$ (1985), pp.590-600.

[11] Accelrys MS materials visualizer, release 4. 0, Accelrys Software, Inc. : San Diego, 2005.

[12] W. Smith, and T.R. Forester, Dl_poly_2.0: A general-purpose parallel molecular dynamics simulation package, Journal of Molecular Graphics. 3 (1996), pp.136-141.

[13] A. Pavese, M. Catti, S.C. Parker, and A. Wall, Modelling of the thermal dependence of structural and elastic properties of calcite, caco ${ }_{32}$ Physics and Chemistry of Minerals. 2 (1996), pp.89-93.

[14] W.L. Jorgensen, J. Chandrasekhar, J.D. Madura, R.W. Impey, and M.L. Klein, Comparison of simple potential functions for simulating liquid water, The Journal of Chemical Physics. 2 (1983), pp.926-935. 


\section{Page 13 of 41}

M. Yang et al.

Table 1 Adsorption energies for peptides adsorbed on the calcite (10 $\overline{1} 4)$ surface

Formatted: Font: Times New Roman, Lowered by $5 \mathrm{pt}$

\begin{tabular}{|c|c|c|c|}
\hline & A & B & C \\
\hline PI $(\mathrm{kJ} / \mathrm{mol})$ & 6.41 & -40.5 & -204.4 \\
\hline PII $(\mathrm{kJ} / \mathrm{mol})$ & 21.4 & -48.6 & -136.8 \\
\hline
\end{tabular}




\section{Figure Captions}

1. Figure 1 Configurations of $\mathrm{R}_{2} \mathrm{E}_{2} \mathrm{~W}_{2} \mathrm{D}_{2}-16$ (PI) and $\mathrm{R}_{2} \mathrm{E}_{2} \mathrm{~W}_{2} \mathrm{D}_{2} \mathrm{P}-17$ (PII). (a) $\mathrm{PI}$ (A); (b) PI (B); (c) PI (C); (d) PII (A); (e) PII (B); (f) PII (C)

2. Figure 2 The calcite $(10 \overline{1} 4)$ surface

3. Figure 3 Simulation model of a peptide molecule on the calcite surface

\begin{tabular}{l}
\hline Deleted: A \\
Formatted: Font: Times New \\
Roman, Lowered by $5 \mathrm{pt}$ \\
\hline Deleted: (10.4) \\
\hline Deleted: a
\end{tabular}

4. Figure 4 Peptides in vacuum. (a) Potential energy; (b) Radius of gyration

5. Figure 5 Potential energy and gyration radius of peptides in water. (a) Potential energy; (b) Radius of gyration

6. Figure 6 Peptides on calcite in water. (a) Potential energy; (b) Radius of gyration

7. Figure 7 Dihedral angles in a peptide repeating unit

8. Figure 8 Dihedral angles for peptides (a) PI (A) in water alone; (b) PI (A) in water on a calcite surface

9. Figure 9 The potential isosurfaces of peptides and a calcite surface. (a) PI (A); (b) PI (B); (c) PI (C); (d) PII (A); (e) PII (B); (f) PII (C) 


\section{Page 15 of 41}

M. Yang et al.

Word account: 2902, words in total.

Deleted: 787

This manuscript is contributed to the special issue "CCP5 Special". 
Font: (Default) Nimbus Roman No9 L, (Asian) Nimbus Roman No9 L

Page 11: [2] Formatted
Font: (Asian) Nimbus Roman No9 Lingjun Yang

Page 11: [3] Formatted Mingjun Yang

11/9/2008 11:55:00 AM

Font: (Asian) Nimbus Roman No9 L, Italic

Page 11: [4] Formatted

Mingjun Yang

11/9/2008 11:55:00 AM

Font: (Asian) Nimbus Roman No9 L

Page 11: [5] Formatted

Mingjun Yang

11/9/2008 11:55:00 AM

Font: (Default) Nimbus Roman No9 L, (Asian) Nimbus Roman No9 L

\begin{tabular}{lll}
\hline Page 11: [6] Formatted & Mingjun Yang & $\mathbf{1 1 / 9 / 2 0 0 8 ~ 1 : 0 6 : 0 0 ~ P M ~}$ \\
Indent: Before: $0 \mathrm{pt}$, Hanging: $32.25 \mathrm{pt}$ & \\
\hline
\end{tabular}

Page 11: [7] Formatted

Mingjun Yang

11/9/2008 11:55:00 AM

Font: (Asian) Nimbus Roman No9 L

Page 11: [8] Formatted

Font: (Asian) Nimbus Roman No9
Mingjun Yang

11/9/2008 11:55:00 AM

Page 11: [9] Formatted
Font: (Asian) Nimbus Roman No9 L

11/9/2008 11:55:00 AM

11/9/2008 11:55:00 AM

Page 11: [10] Formatted Mingjun Yang

Font: (Default) Nimbus Roman No9 L, (Asian) Nimbus Roman No9 L

Mingjun Yang

11/9/2008 11:55:00 AM

Font: (Asian) Nimbus Roman No9 L

Page 11: [12] Formatted Mingjun Yang

11/9/2008 11:55:00 AM

Font: (Asian) Nimbus Roman No9 L, Italic

Page 11: [13] Formatted Mingjun Yang

11/9/2008 11:55:00 AM

Font: (Asian) Nimbus Roman No9 L

Page 11: [14] Formatted Mingjun Yang

11/9/2008 11:55:00 AM

Font: (Default) Nimbus Roman No9 L, (Asian) Nimbus Roman No9 L

Page 11: [15] Formatted

Mingjun Yang

11/9/2008 11:55:00 AM

Font: (Asian) Nimbus Roman No9 L

Page 11: [16] Formatted

Mingjun Yang

11/9/2008 11:55:00 AM

Font: (Asian) Nimbus Roman No9 L, Italic

Page 11: [17] Formatted Mingjun Yang

11/9/2008 11:55:00 AM

Font: (Asian) Nimbus Roman No9 L

\begin{tabular}{lll}
\hline Page 11: [18] Formatted & Mingjun Yang & 11/9/2008 11:55:00 AM
\end{tabular}

Font: (Default) Nimbus Roman No9 L, (Asian) Nimbus Roman No9 L

Page 11: [19] Formatted

Mingjun Yang

11/9/2008 11:55:00 AM

Font: (Asian) Nimbus Roman No9 L

Page 11: [20] Formatted

Mingjun Yang

11/9/2008 11:55:00 AM

http://mc.manuscriptcentral.com/tandf/jenmol 
Font: (Asian) Nimbus Roman No9 L, Italic

\begin{tabular}{|c|c|c|}
\hline Page 11: [21] Formatted & Mingjun Yang & $11 / 9 / 2008$ 11:55:00 AM \\
\hline Font: (Asian) Nimbus & $\mathrm{L}$ & \\
\hline Page 11: [22] Formatted & Mingjun Yang & 11/9/2008 11:55:00 AM \\
\hline
\end{tabular}

Page 11: [23] Formatted

Mingjun Yang

11/9/2008 11:55:00 AM

Font: (Asian) Nimbus Roman No9 L

\begin{tabular}{|c|c|c|}
\hline Page 11: [24] Formatted & Mingjun Yang & 11/9/2008 11:55:00 AM \\
\hline Font: (Asian) Nimbu & L, Italic & \\
\hline Page 11: [25] Formatted & Mingjun Yang & $11 / 9 / 2008$ 11:55:00 AM \\
\hline
\end{tabular}
Mingjun Yang

11/9/2008 11:55:00 AM

[1] J.P. Reyes-Grajeda, A. Moreno, and A. Romero, Crystal structure of ovocleidin-17, a major protein of the calcified gallus gallus eggshell - implications in the calcite mineral growth pattern, Journal of Biological Chemistry. 39 (2004), pp.4087640881.

[2] P.K. Ajikumar, S. Vivekanandan, R. Lakshminarayanan, S.D.S. Jois, R.M. Kini, and S. Valiyaveettil, Mimicking the function of eggshell matrix proteins: The role of multiplets of charged amino acid residues and self-assembly of peptides in biomineralization, Angewandte Chemie-International Edition. 34 (2005), pp.5476-5479.

[3] R.A. Metzler, I.W. Kim, K. Delak, J.S. Evans, D. Zhou, E. Beniash, F. Wilt, M. Abrecht, J.W. Chiou, J.H. Guo, S.N. Coppersmith, and P. Gilbert, Probing the organic-mineral interface at the molecular level in model biominerals, Langmuir. 6 (2008), pp.2680-2687.

[4] S. Collino, and J.S. Evans, Structural features that distinguish kinetically distinct biomineralization polypeptides, Biomacromolecules. 5 (2007), pp.1686-1694.

[5] D.M. Duffy, and J.H. Harding, Simulation of organic monolayers as templates for the nucleation of calcite crystals, Langmuir. 18 (2004), pp.7630-7636.

[6] C.L. Freeman, J.H. Harding, D.J. Cooke, J.A. Elliott, J.S. Lardge, and D.M. Duffy, New forcefields for modeling biomineralization processes, Journal of Physical Chemistry C. 32 (2007), pp.11943-11951.

[7] M. Yang, S.L.S. Stipp, and J. Harding, Biological control on calcite crystallization by polysaccharides, Crystal Growth \& Design. (2008), in press.

[8] N.A. Baker, D. Sept, S. Joseph, M.J. Holst, and J.A. McCammon, Electrostatics of nanosystems: Application to microtubules and the ribosome, Proceedings of the National Academy of Sciences of the United States of America. 18 (2001), pp.10037-10041.

[9] D.A. Case, T.A. Darden, I. T.E. Cheatham, C.L. Slimmerling, J. Wang, R.E. Duke, R. Luo, K.M. Merz, D.A. Pearlman, M. Crowley, R.C. Walker, W. Zhang, B. Wang, S. Hayik, A. Roitberg, G. Seabra, K.F. Wong, F. Paesani, X. Wu, S. Brozell, V. Tsui, H. Gohlke, L. Yang, C. Tan, J. Mongan, V. Hornak, G. Cui, P. Beroza, D.H. Mathews, C. Schafmeister, W.S. Ross, and P.A. Kollman Amber 9, University of California: San Francisco, 2006. 
[10] S.A. Markgraf, and R.J. Reeder, High-temperature structure refinements of calcite and magnesite, American Mineralogist. 5-6 (1985), pp.590-600.

[11] Accelrys Ms materials visualizer, release 4.0, Accelrys Software, Inc.: San Diego, 2005.

[12] W. Smith, and T.R. Forester, Dl_poly_2.0: A general-purpose parallel molecular dynamics simulation package, Journal of Molecular Graphics. 3 (1996), pp.136141.

[13] A. Pavese, M. Catti, S.C. Parker, and A. Wall, Modelling of the thermal dependence of structural and elastic properties of calcite, $\mathrm{Caco}_{3}$, Physics and Chemistry of Minerals. 2 (1996), pp.89-93.

[14] W.L. Jorgensen, J. Chandrasekhar, J.D. Madura, R.W. Impey, and M.L. Klein, Comparison of simple potential functions for simulating liquid water, The Journal of Chemical Physics. 2 (1983), pp.926-935. 


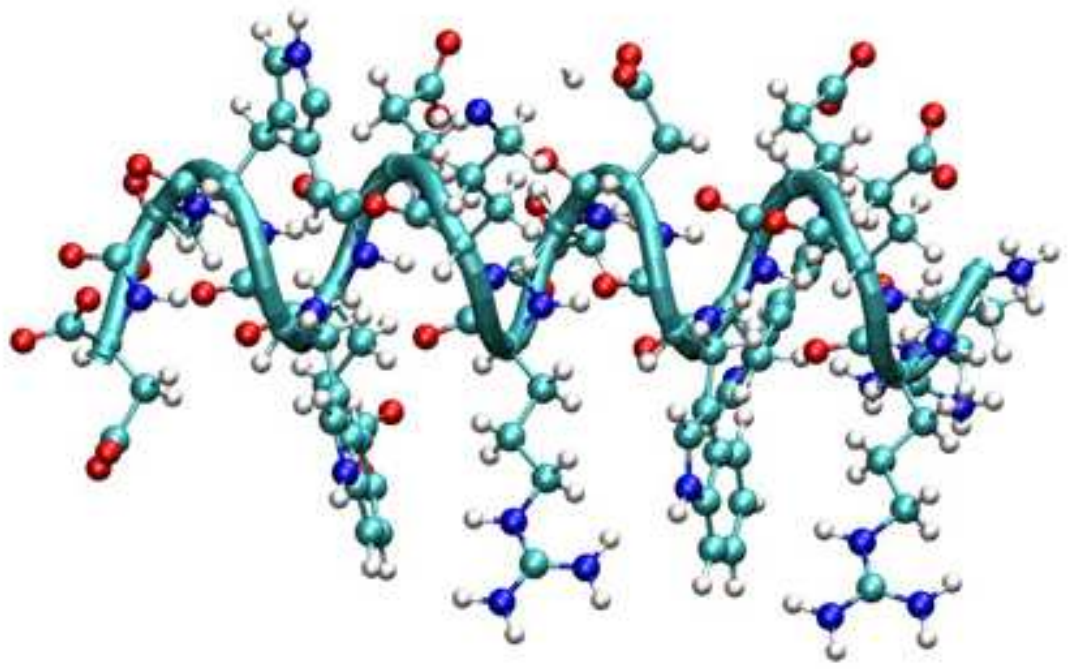

$36 \times 23 \mathrm{~mm}(300 \times 300 \mathrm{DPI})$

29

31

32

33

34

36

37

39

40

41

42

44

45

47

48

49

51

52

53

54

55

56

57

59

60

http://mc.manuscriptcentral.com/tandf/jenmol 


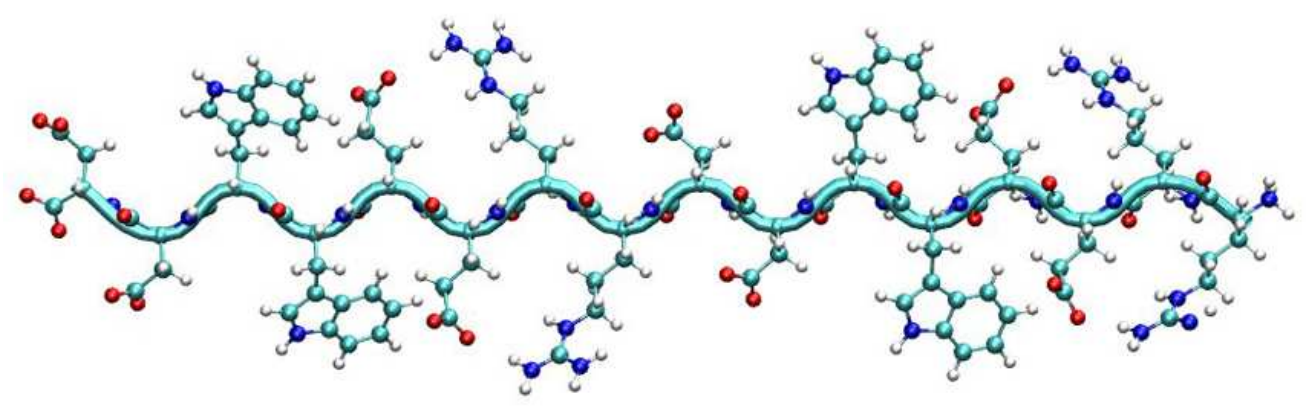

$72 \times 23 \mathrm{~mm}(300 \times 300 \mathrm{DPI})$ 


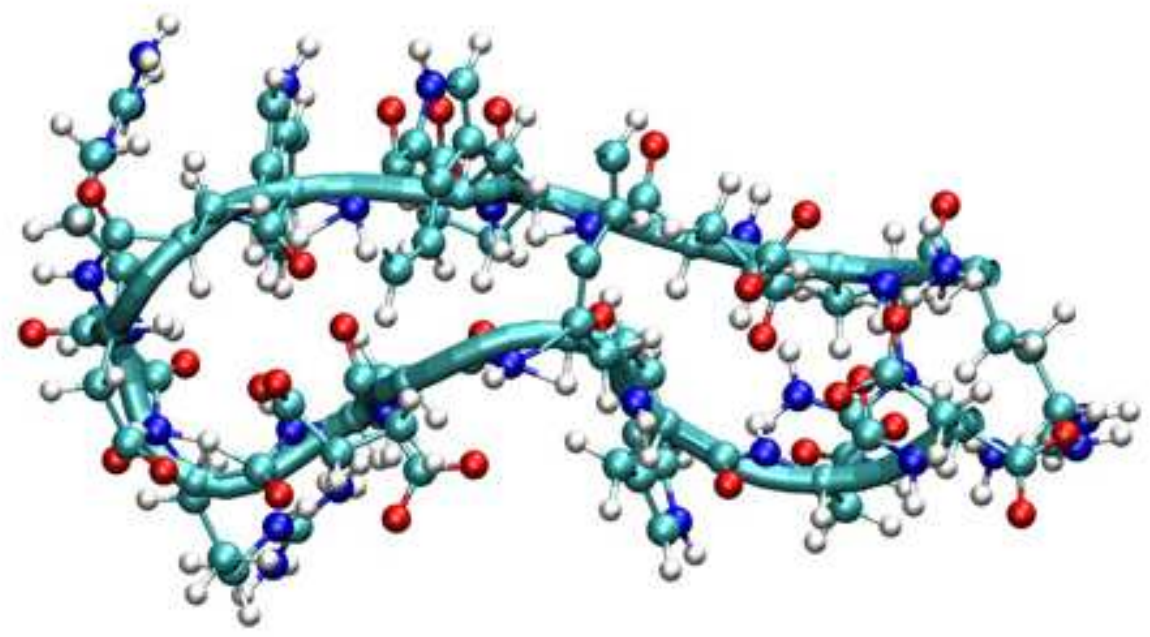

$40 \times 23 \mathrm{~mm}(300 \times 300$ DPI $)$ 


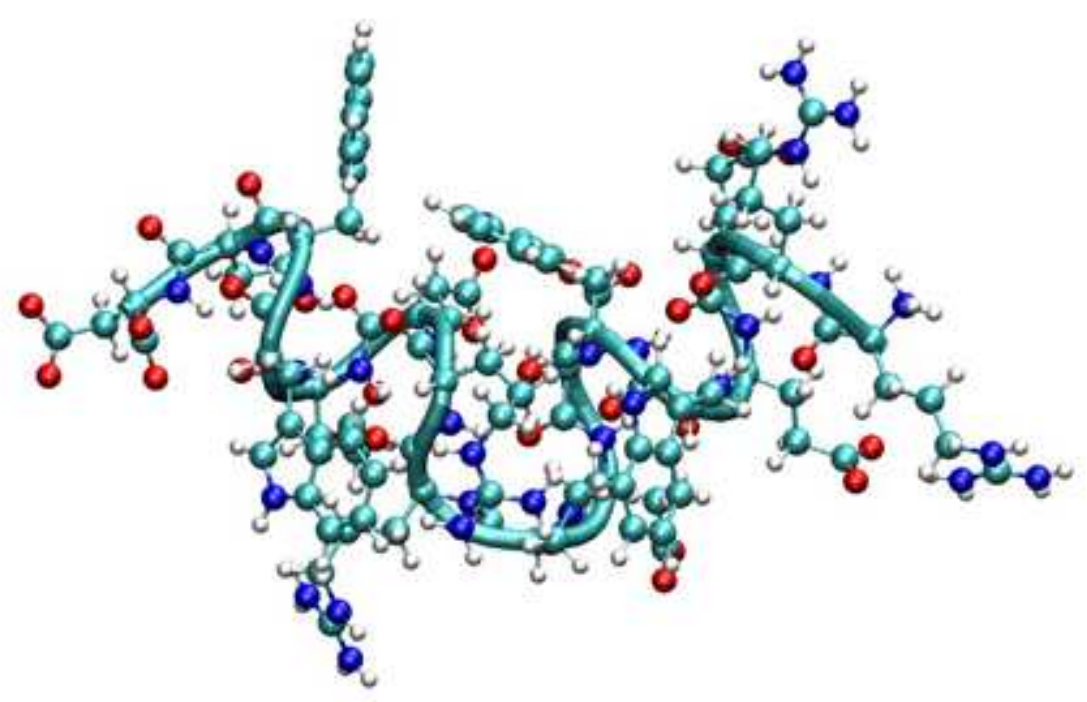

$36 \times 23 \mathrm{~mm}(300 \times 300 \mathrm{DPI})$

http://mc.manuscriptcentral.com/tandf/jenmol 


\section{Page 23 of 41}

1

2

3

4

5

7

8

9

10

11

12

13

14

15

16

17

18

19

20

21

22

$63 \times 23 \mathrm{~mm}(300 \times 300 \mathrm{DPI})$

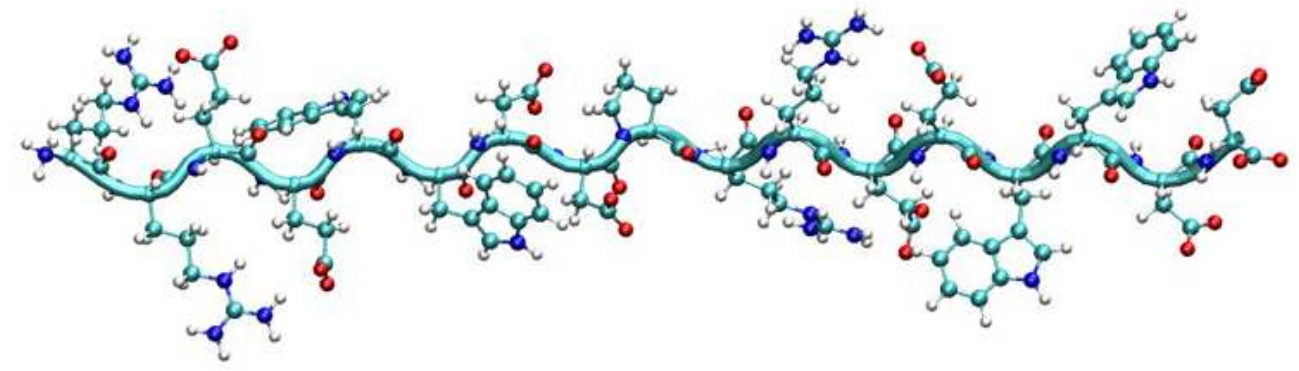

24

25

26

27

28

29

30

31

32

33

34

35

36

37

38

39

40

41

42

43

44

45

46

47

48

49

50

51

52

53

54

55

56

57

58

59

60

http://mc.manuscriptcentral.com/tandf/jenmol 


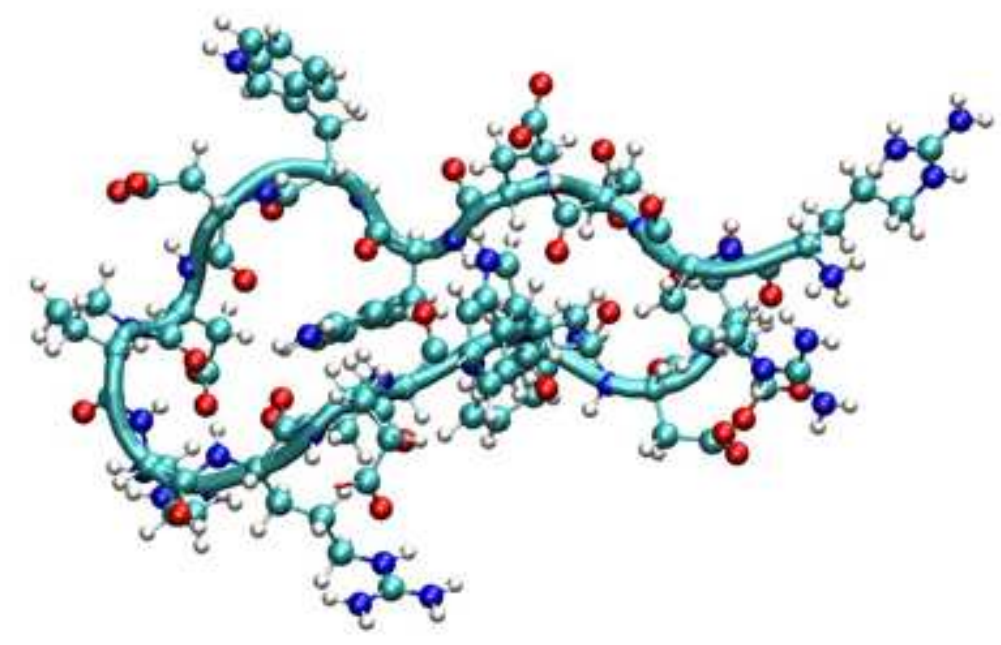

$33 \times 23 \mathrm{~mm}(300 \times 300 \mathrm{DPI})$

http://mc.manuscriptcentral.com/tandf/jenmol 


\section{Page 25 of 41}

1

2

3

4

5

6
7

8

9

10

11

12

13

14

15

16

17

18

19

20

21

22

23

24

25

26

27

28

29

30

31

32

33

34

35

36

37

38

39

40

41

42

43

44

45

46

47

48

49

50

51

52

53

54

55

56

57

58

59

60
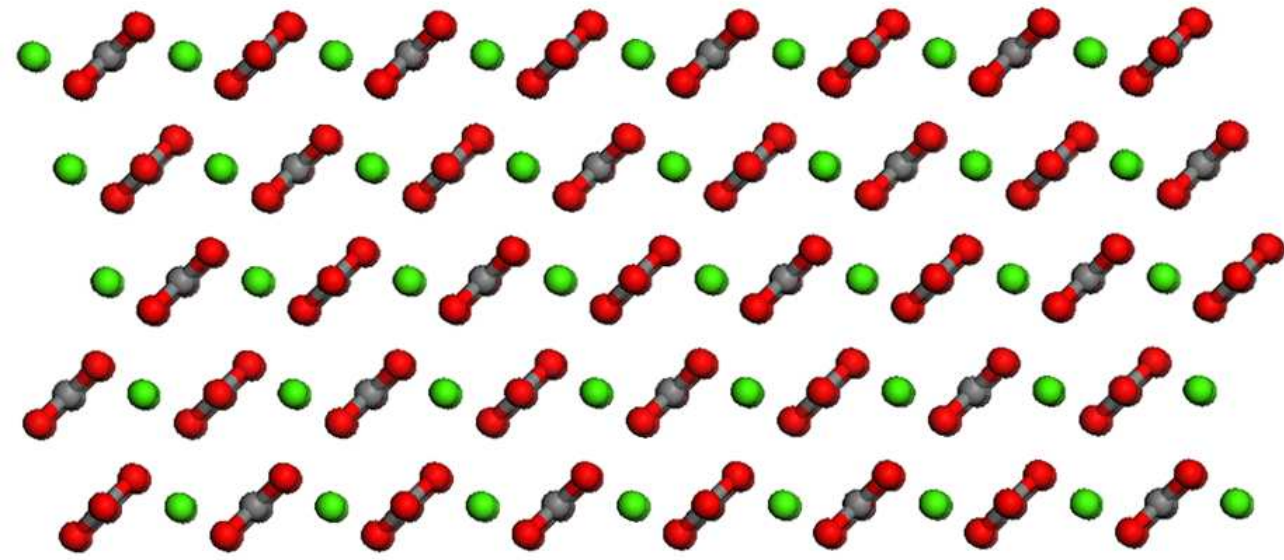

Figure 2 Calcite (10.4) surface

$78 \times 34 \mathrm{~mm}(300 \times 300$ DPI) 


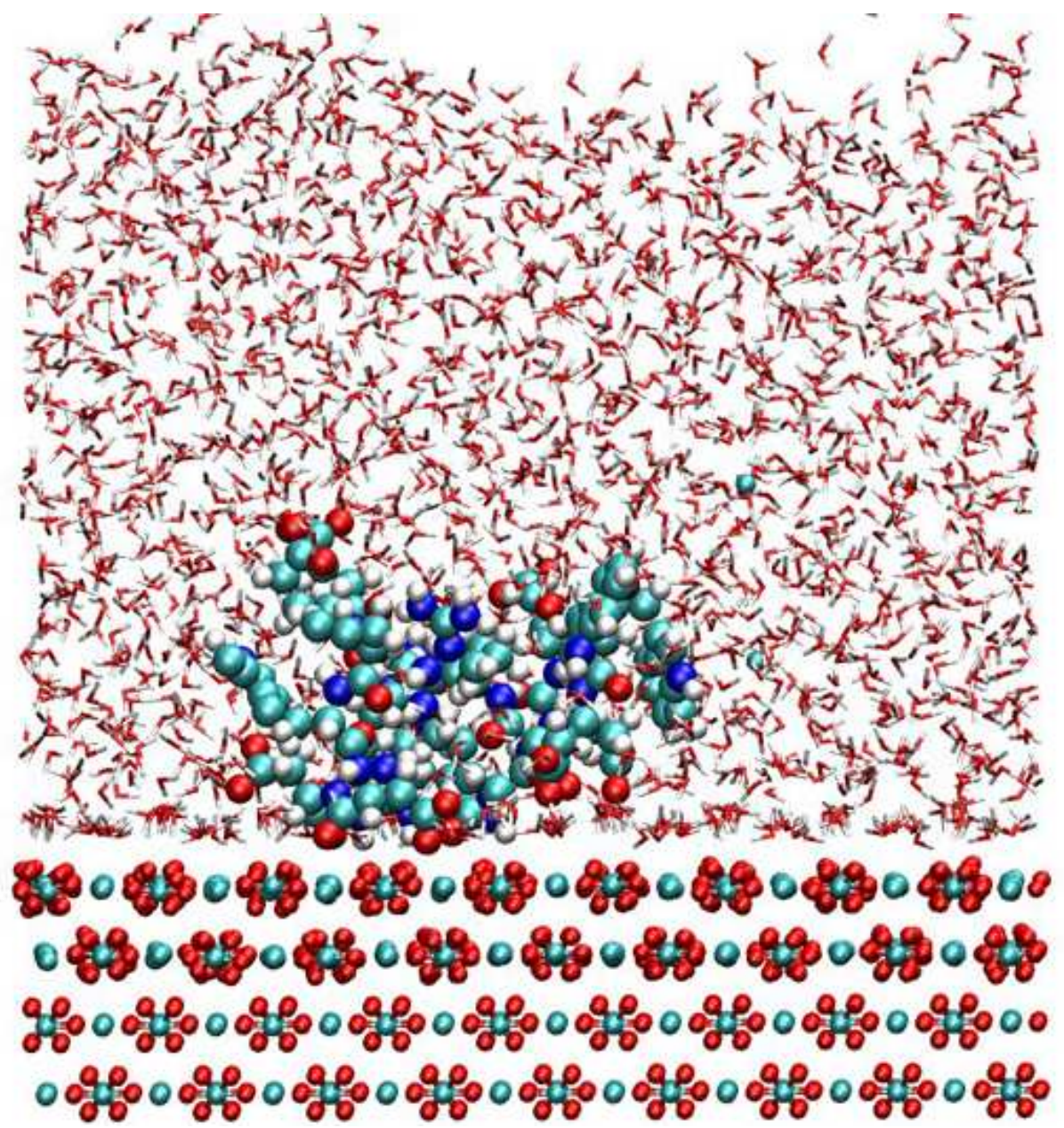

Figure 3 Simulation model of peptide molecule on calcite surface $46 \times 44 \mathrm{~mm}(300 \times 300$ DPI $)$ 


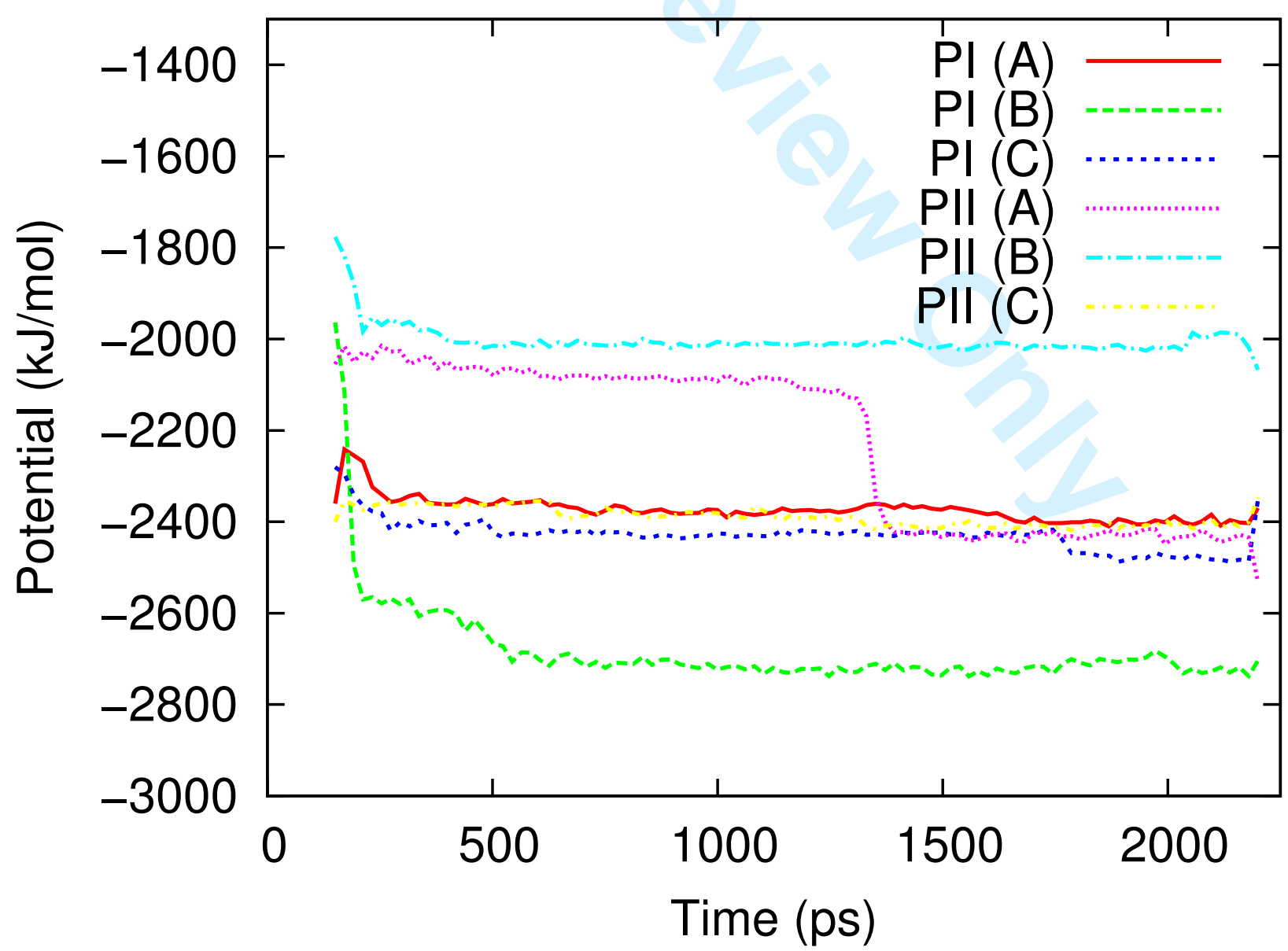

http://mc.manuscriptcentral.com/tandf/jenmol 


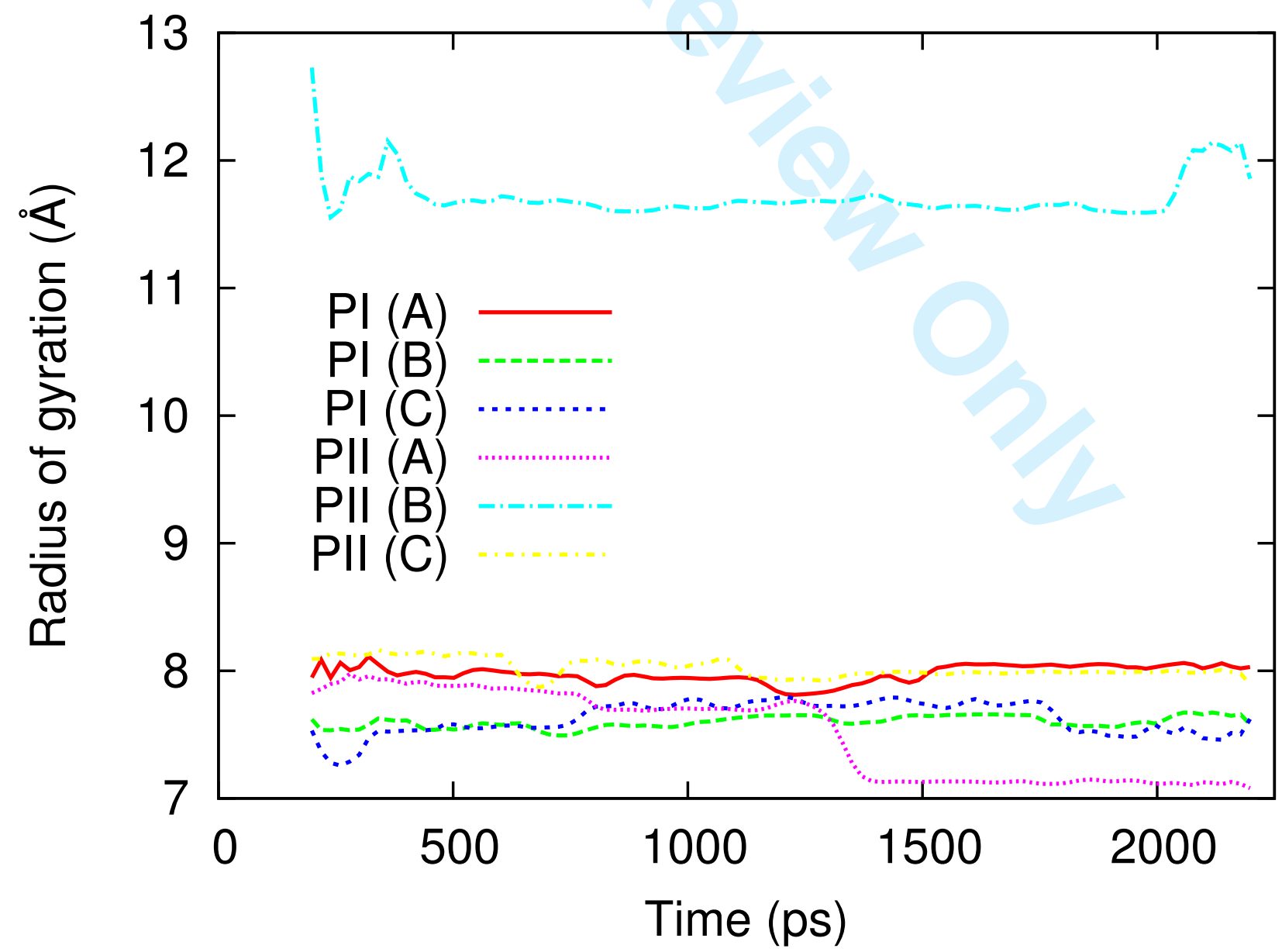

http://mc.manuscriptcentral.com/tandf/jenmol 


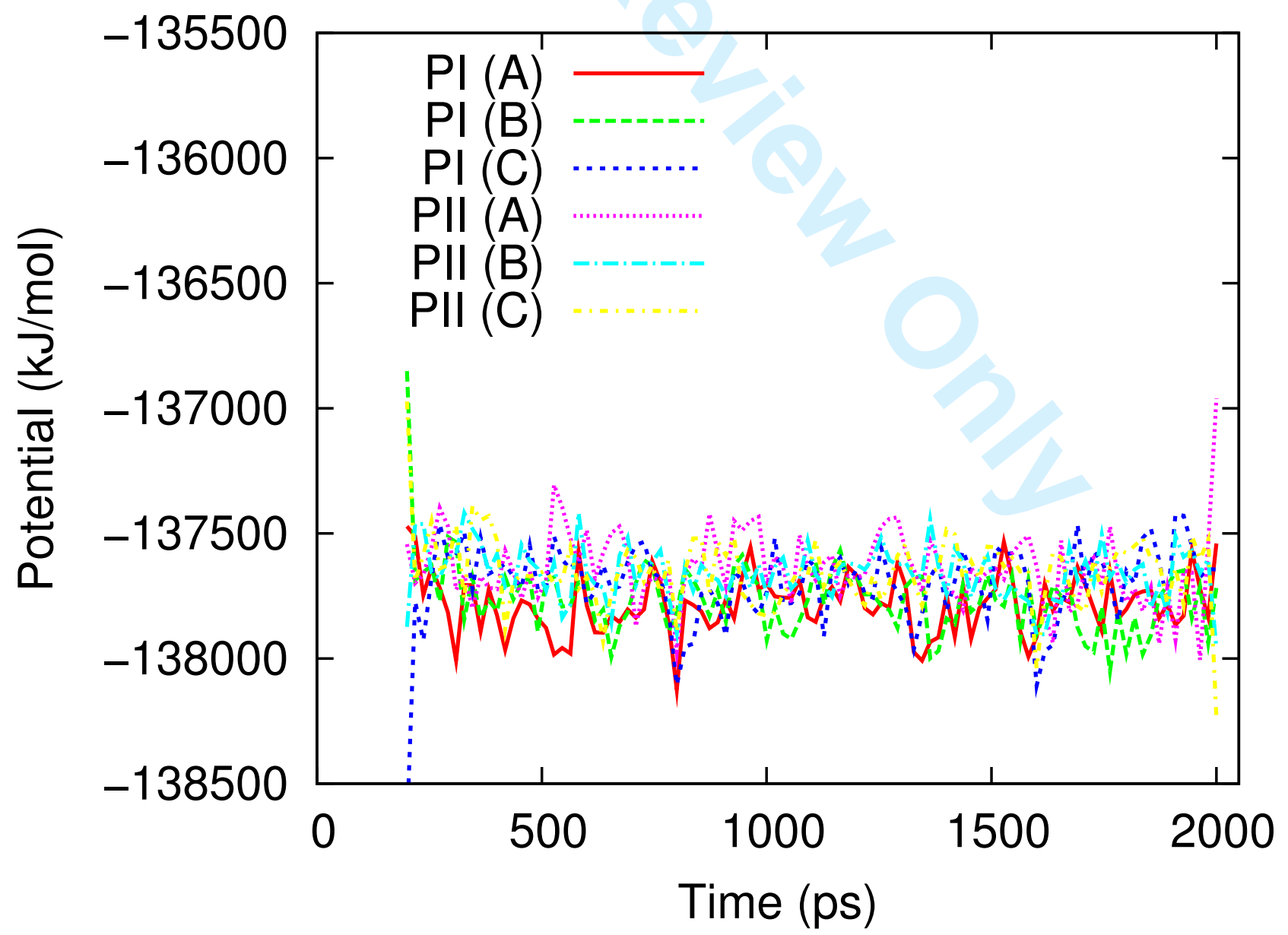

http://mc.manuscriptcentral.com/tandf/jenmol 


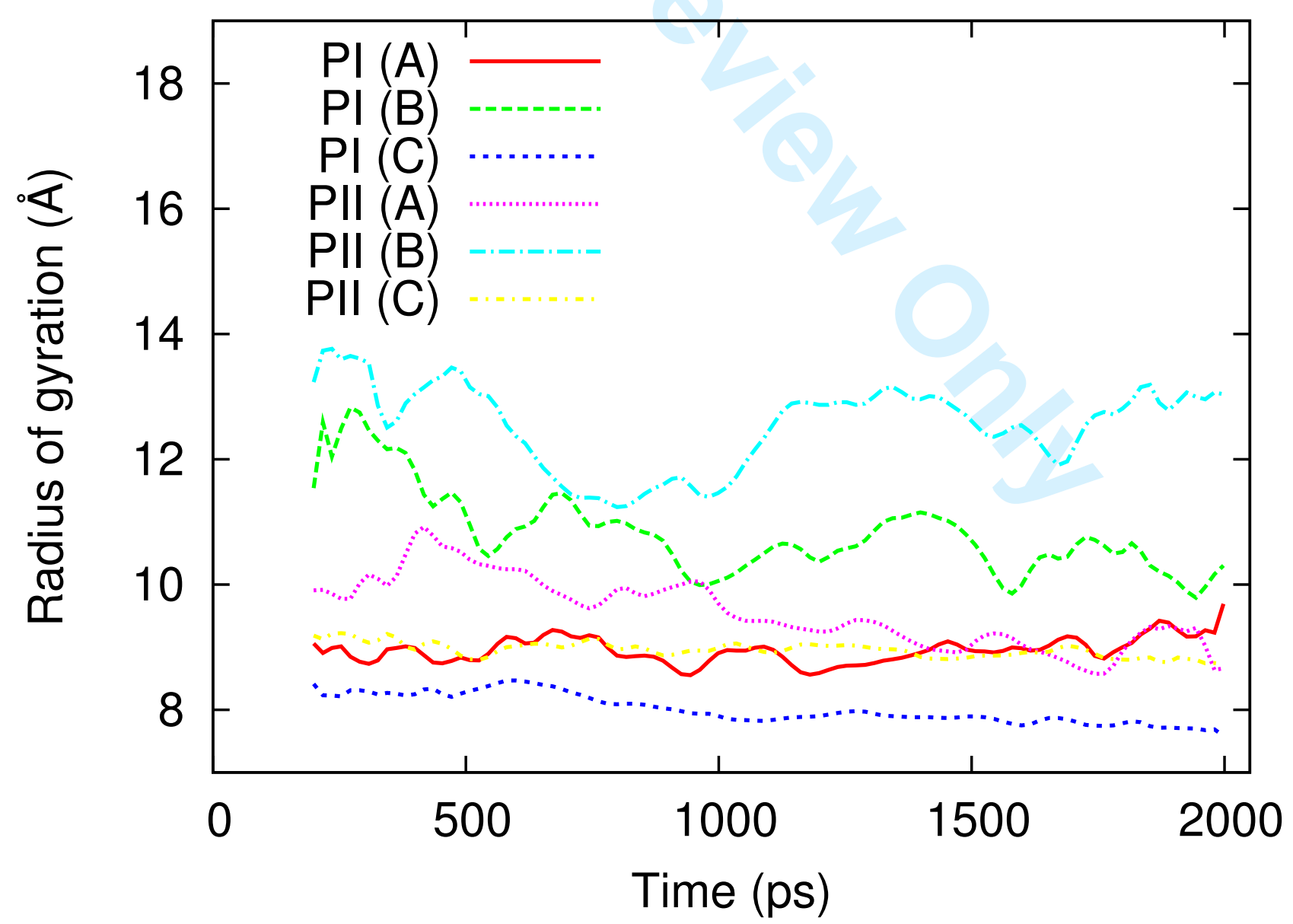

http://mc.manuscriptcentral.com/tandf/jenmol 


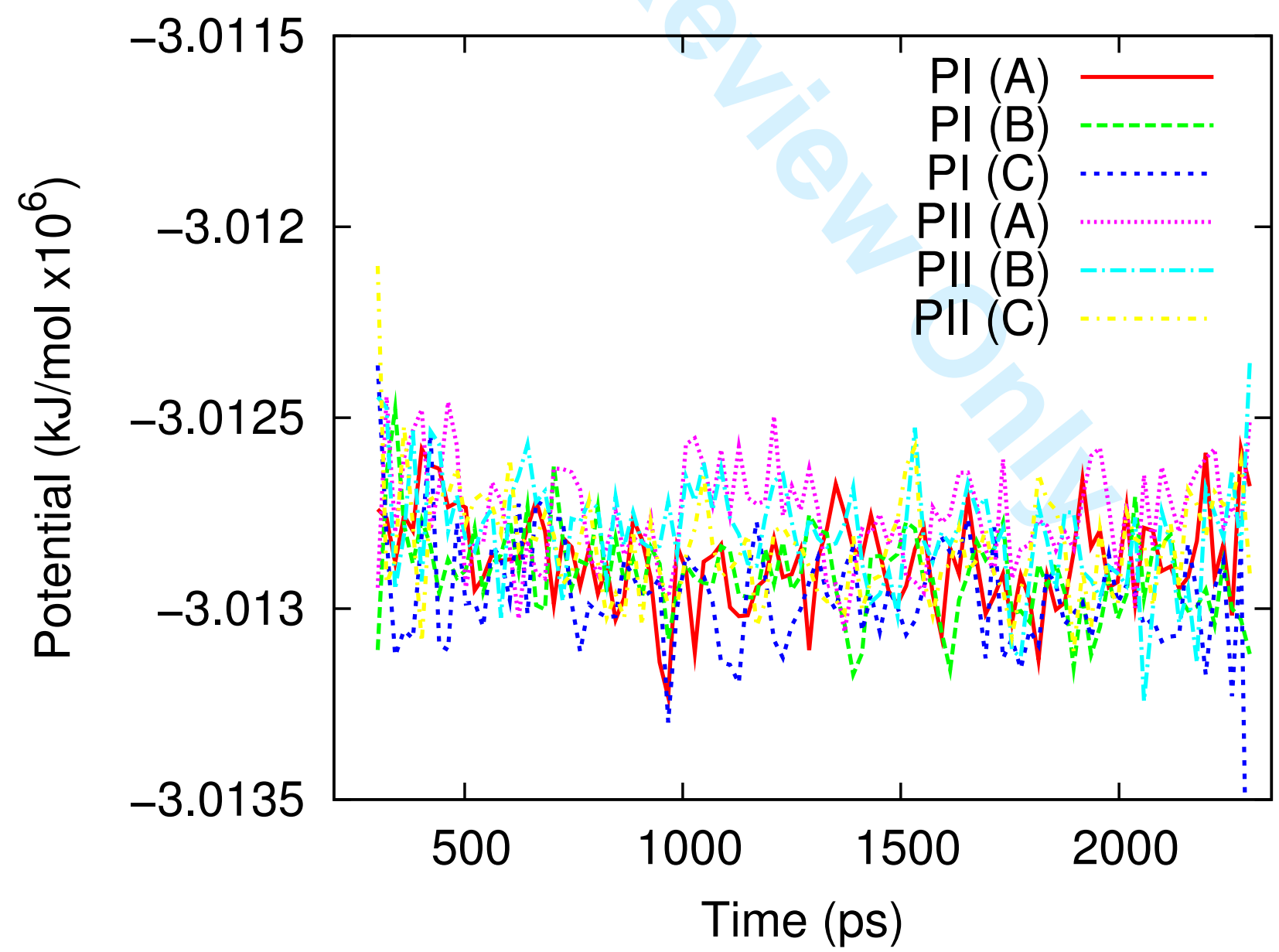

http://mc.manuscriptcentral.com/tandf/jenmol 


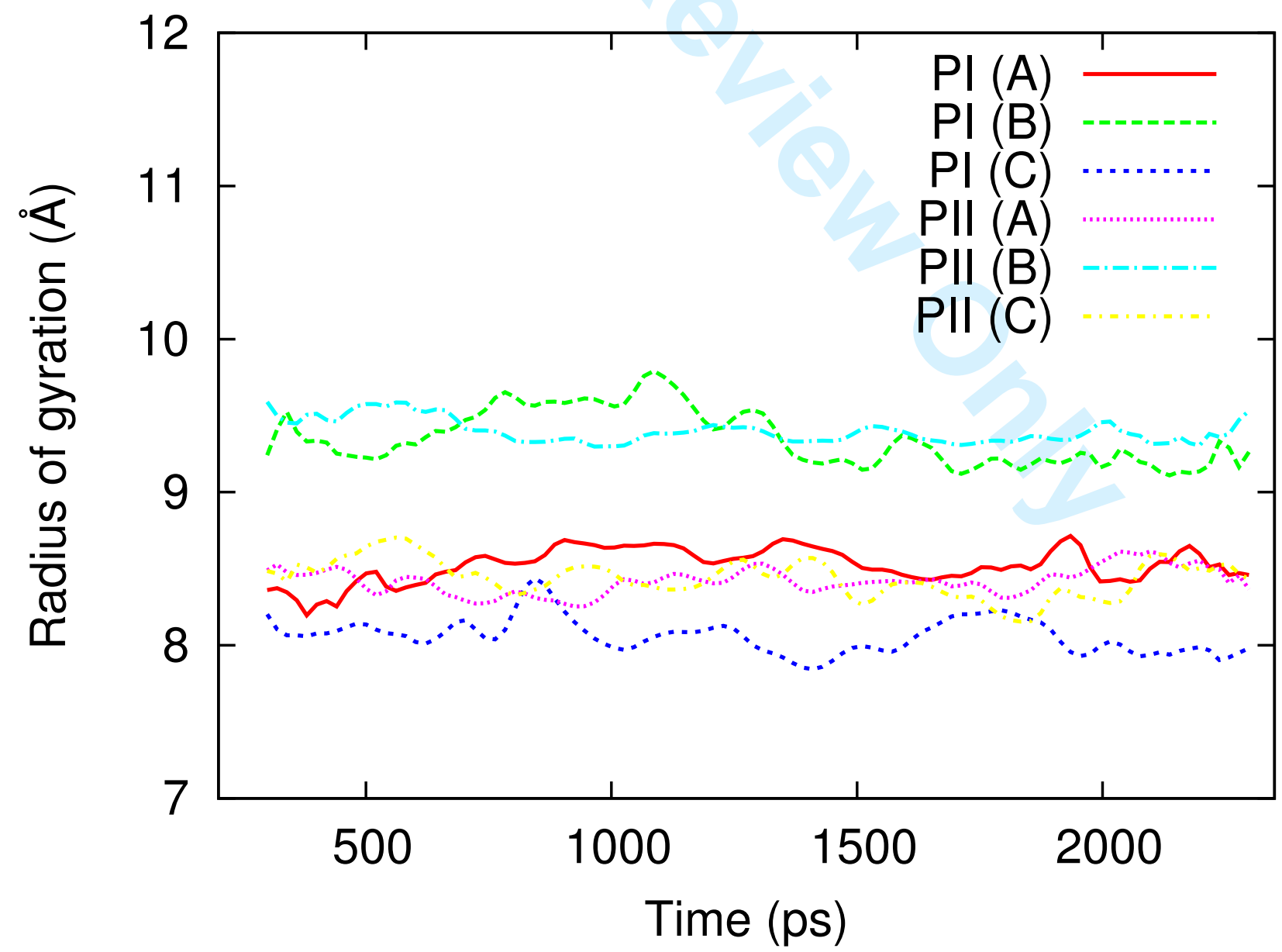

http://mc.manuscriptcentral.com/tandf/jenmol 


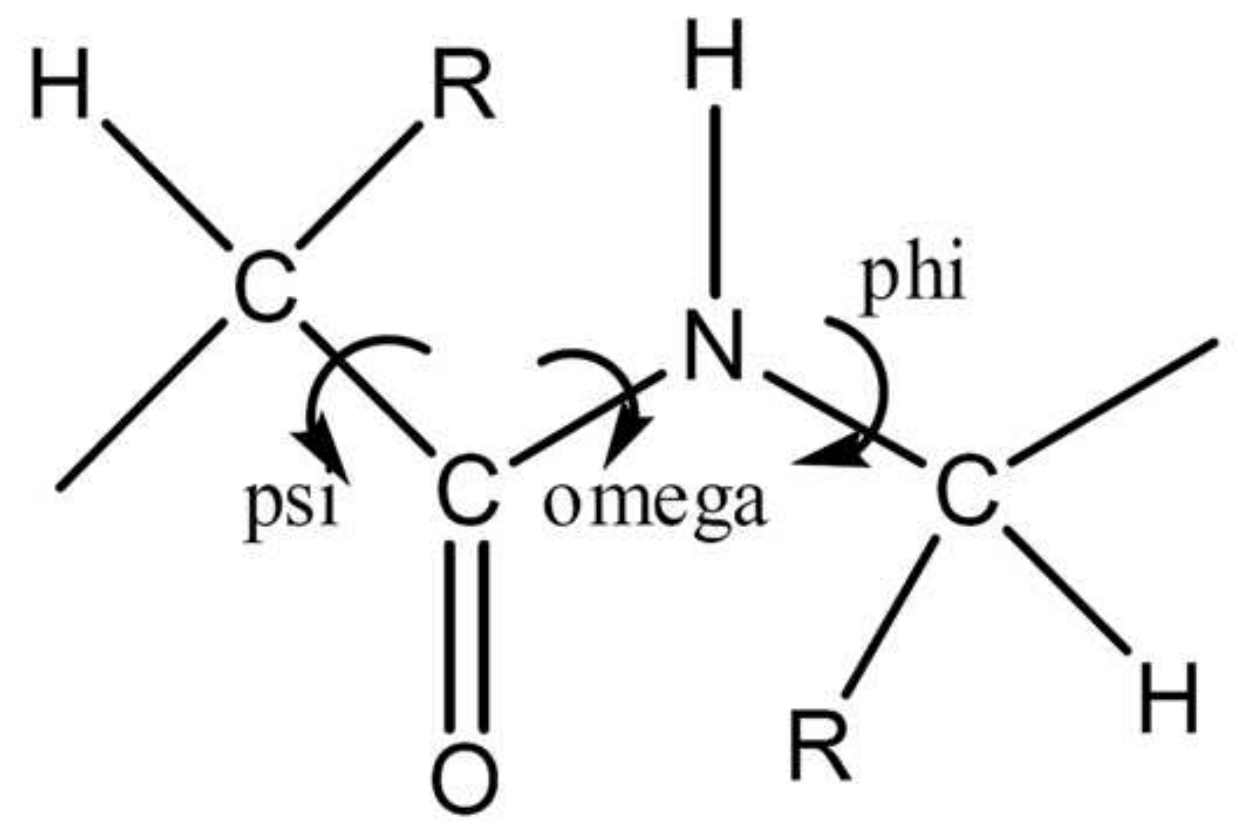

$23 \times 14 \mathrm{~mm}(600 \times 600 \mathrm{DPI})$ 


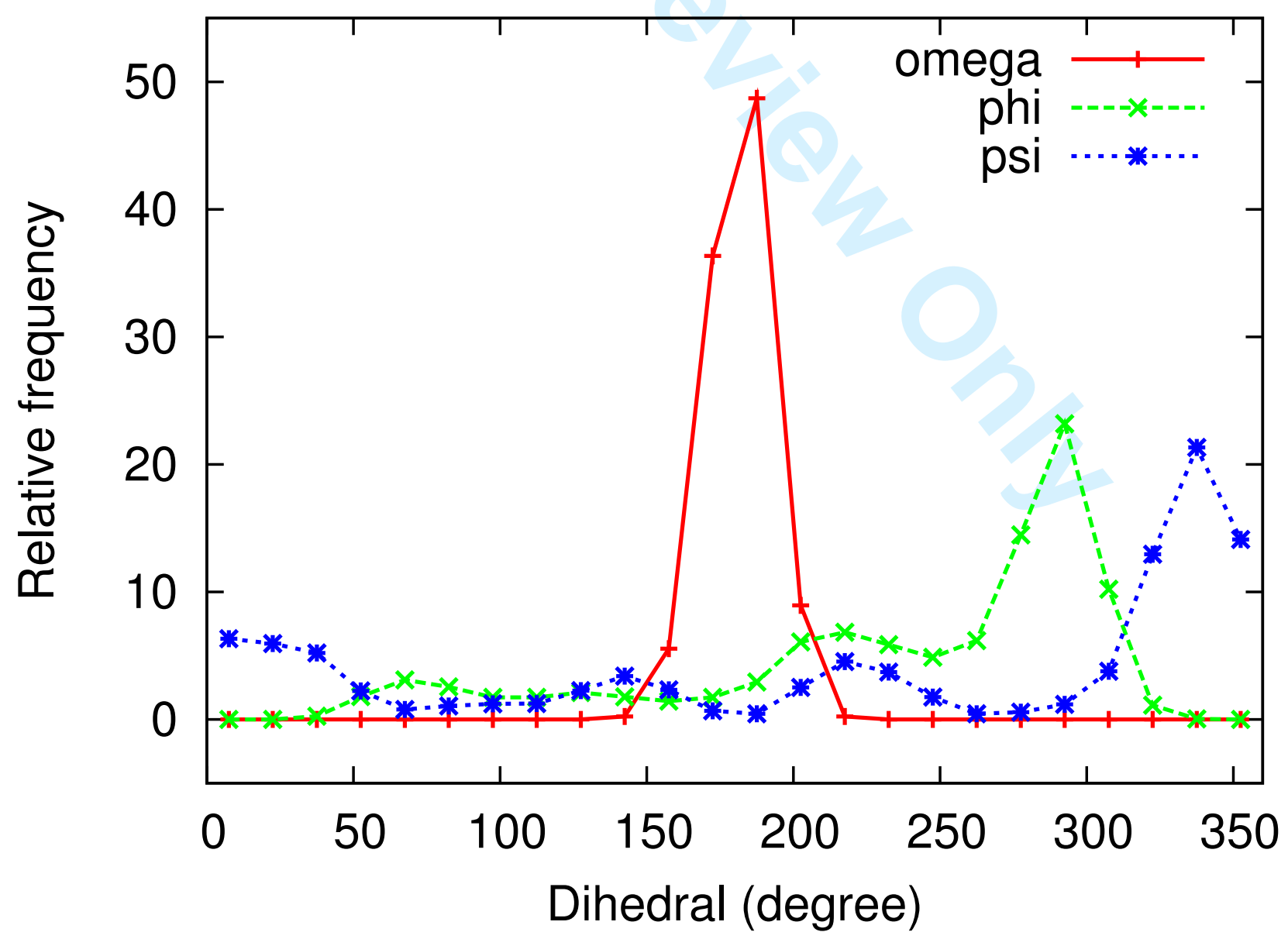

http://mc.manuscriptcentral.com/tandf/jenmol 


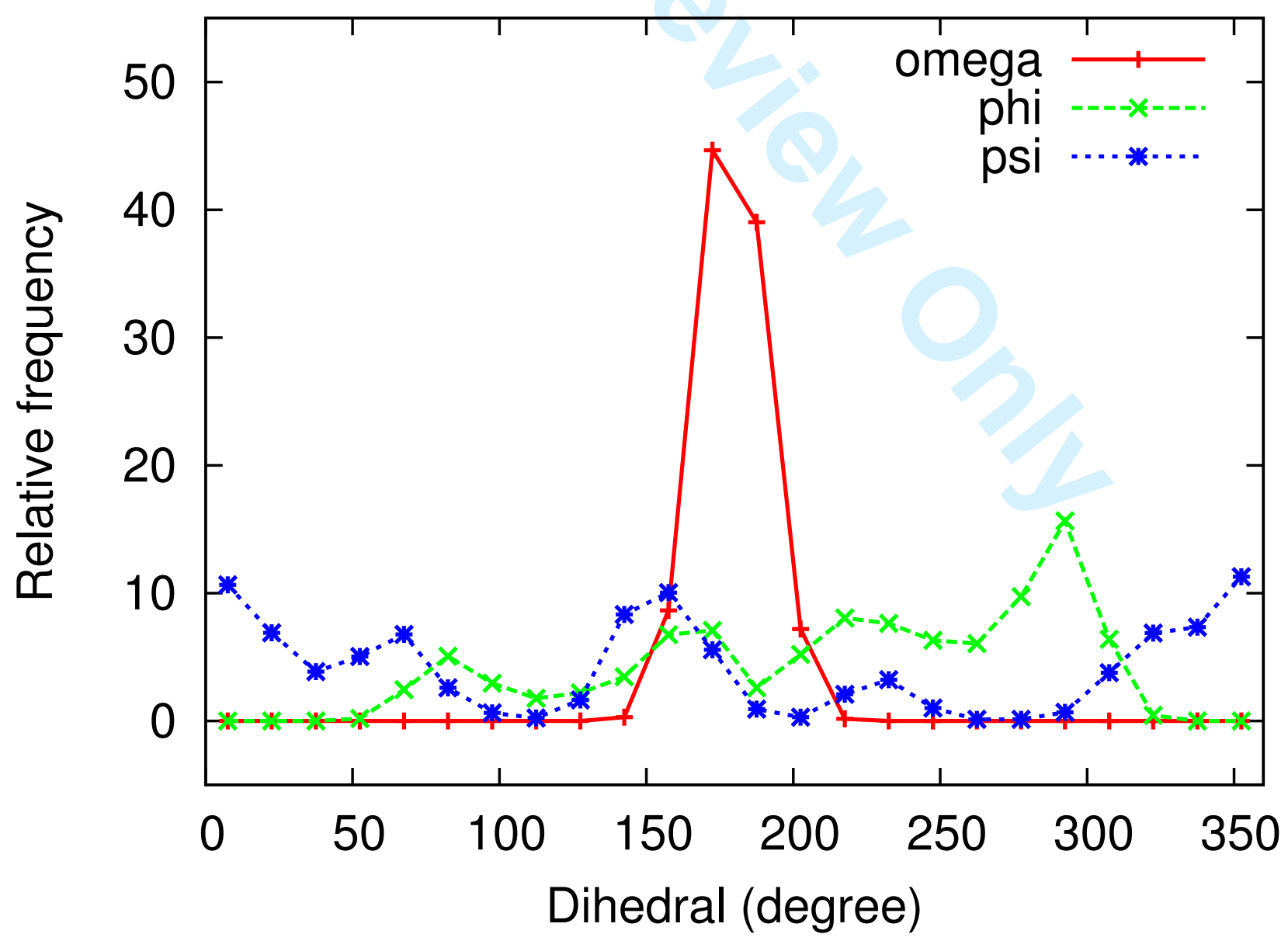

http://mc.manuscriptcentral.com/tandf/jenmol 


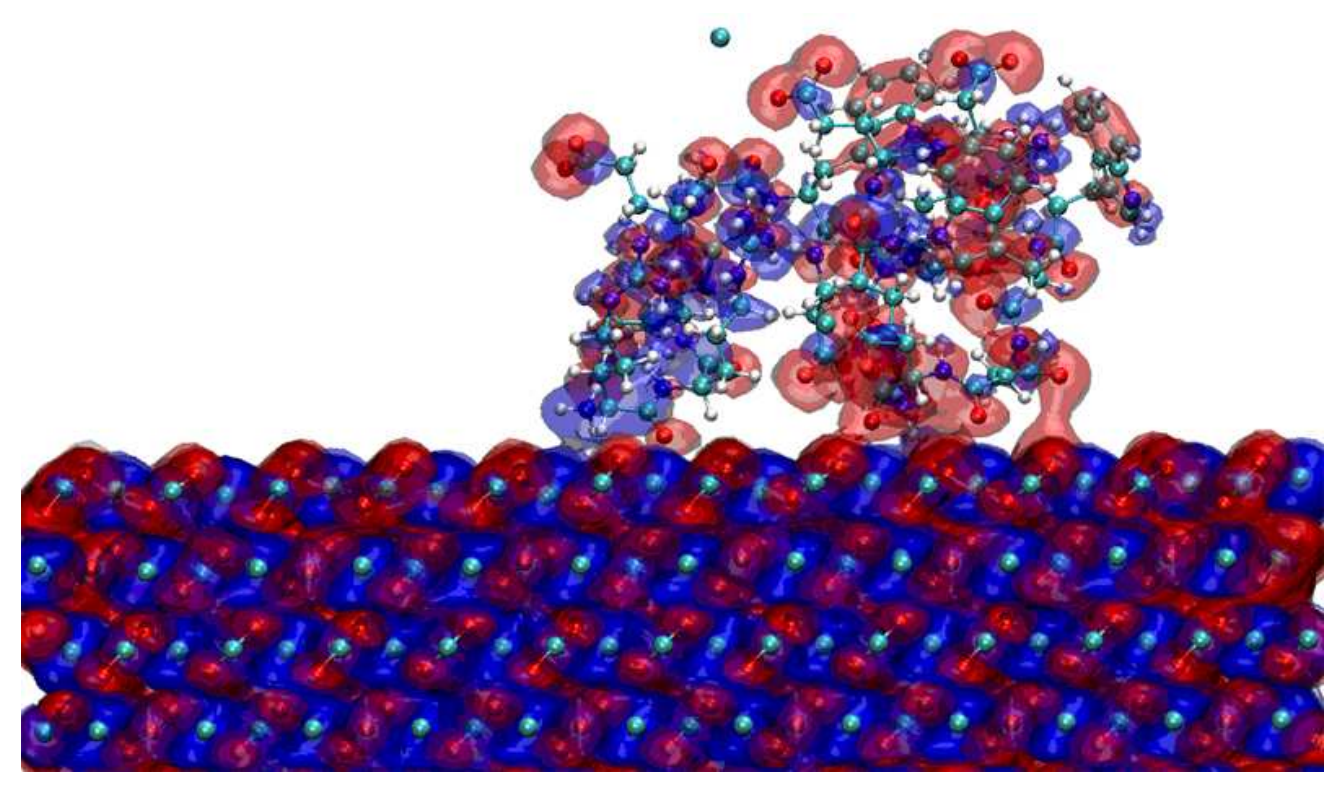

67×39mm (300 x 300 DPI)

1
2
3
4
5
6
7
8
9
10
11
12
13
14
15
16
17
18
19
20
21
22
23
24
25
26
27
28
29
30
31
32
33
34
35
36
37
38
39
40
41
42
43
44
45
46
47
48
49
50
51
52
53
54
55
56
57
50




\section{Page 37 of 41}

1
2
3
4
5
6
7
8
9
10
11
12
13
14
15
16
17
18
19
20
21
22
23
24
25
26
27
28
29
30
31
32
33
34
35
36
37
38
39
40
41
42
43
44
45
46
47
50
58
59
50
52
53
50

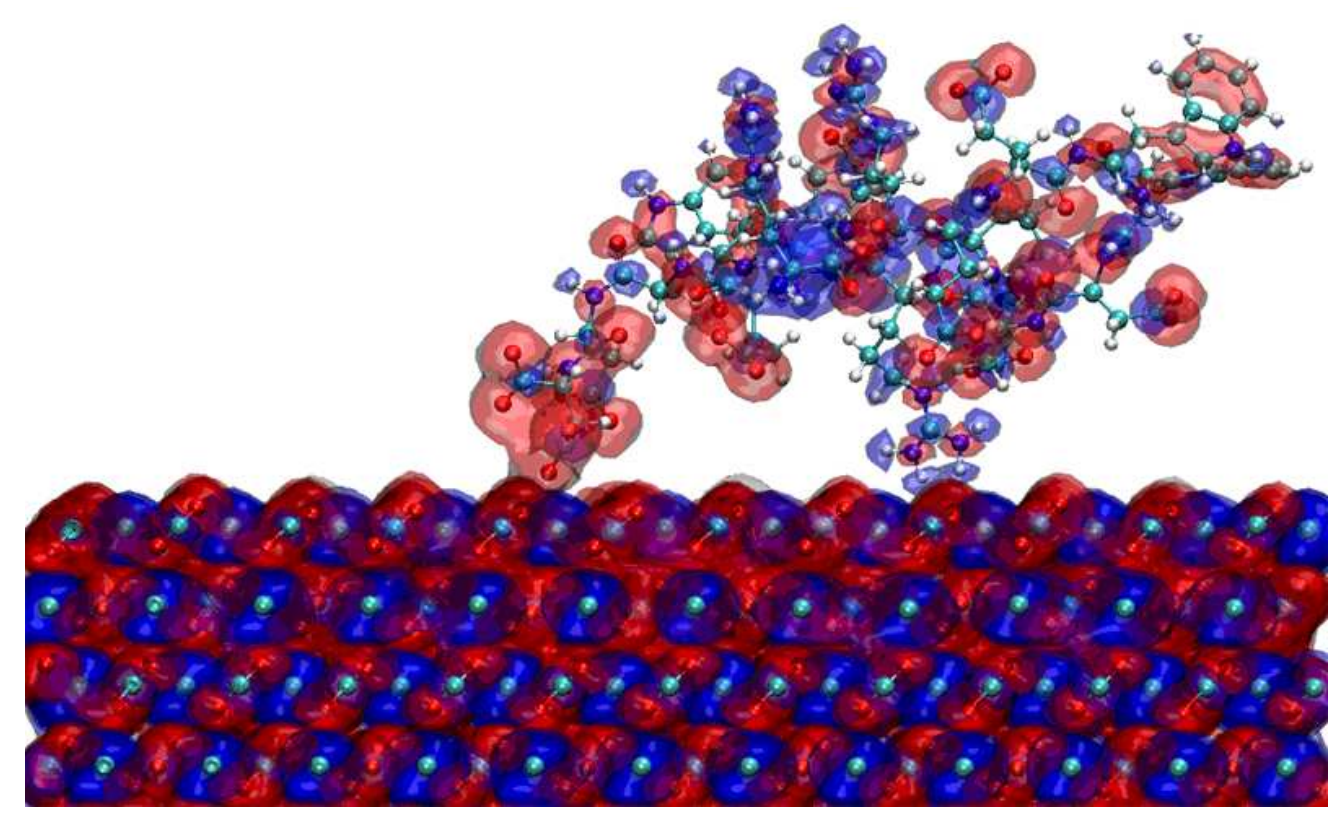

$67 \times 41 \mathrm{~mm}(300 \times 300$ DPI $)$

http://mc.manuscriptcentral.com/tandf/jenmol 


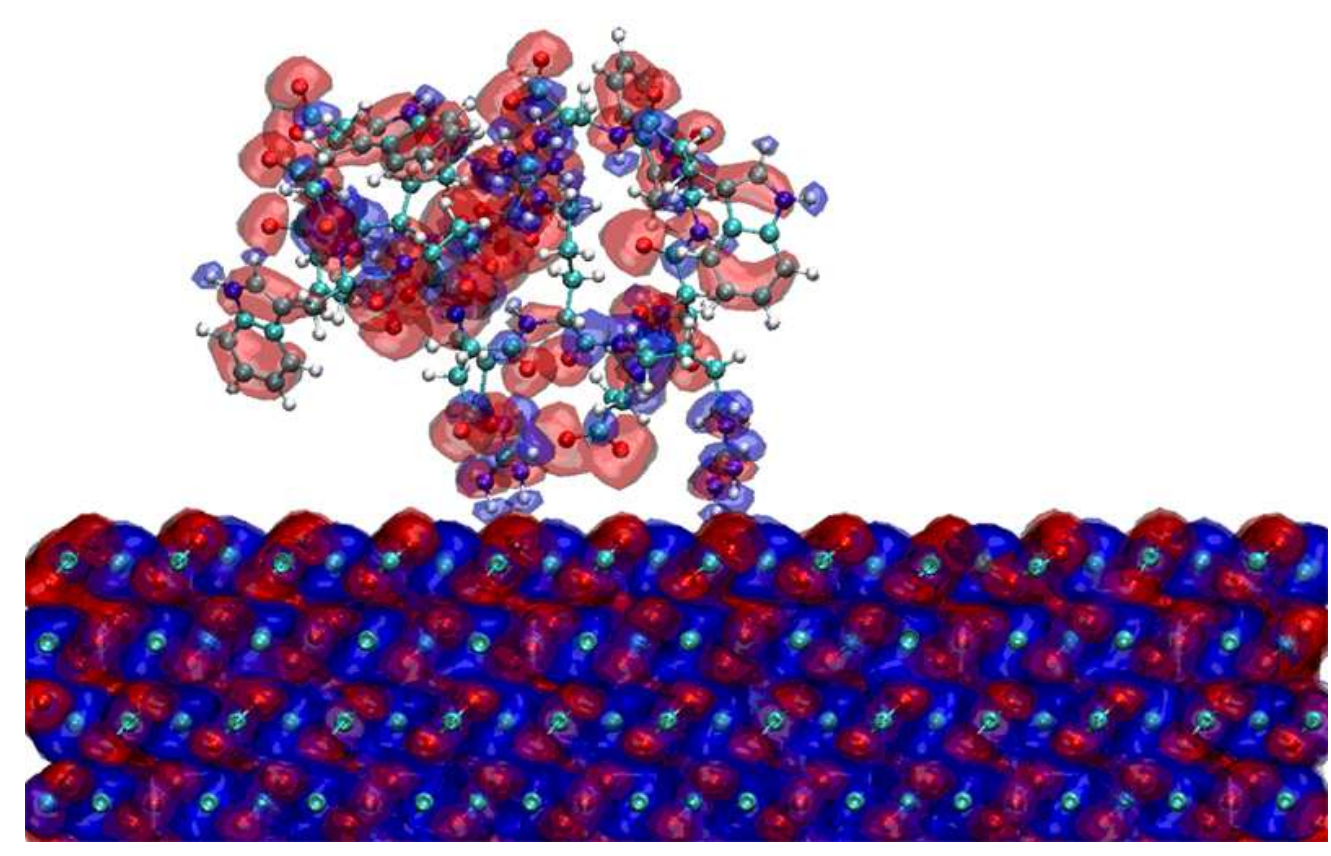

$67 \times 42 \mathrm{~mm}(300 \times 300 \mathrm{DPI})$

31
32
33
34
35
36
37
38
39
40
41
42
43
44
45
46
47
48
49
50
51
52
53
54
55
56
57
58
59
60

http://mc.manuscriptcentral.com/tandf/jenmol 


\section{Page 39 of 41}

1
1
3
4
5
6
7
8
9
10
11
12
13
14
15
16
17
18
19
20
21
22
23
24
25
26
27
28
29
30
31
32
33
34
35
36
37
38
39
40
41
42
43
44
55
50
56
57
48
59
50
51
53
50

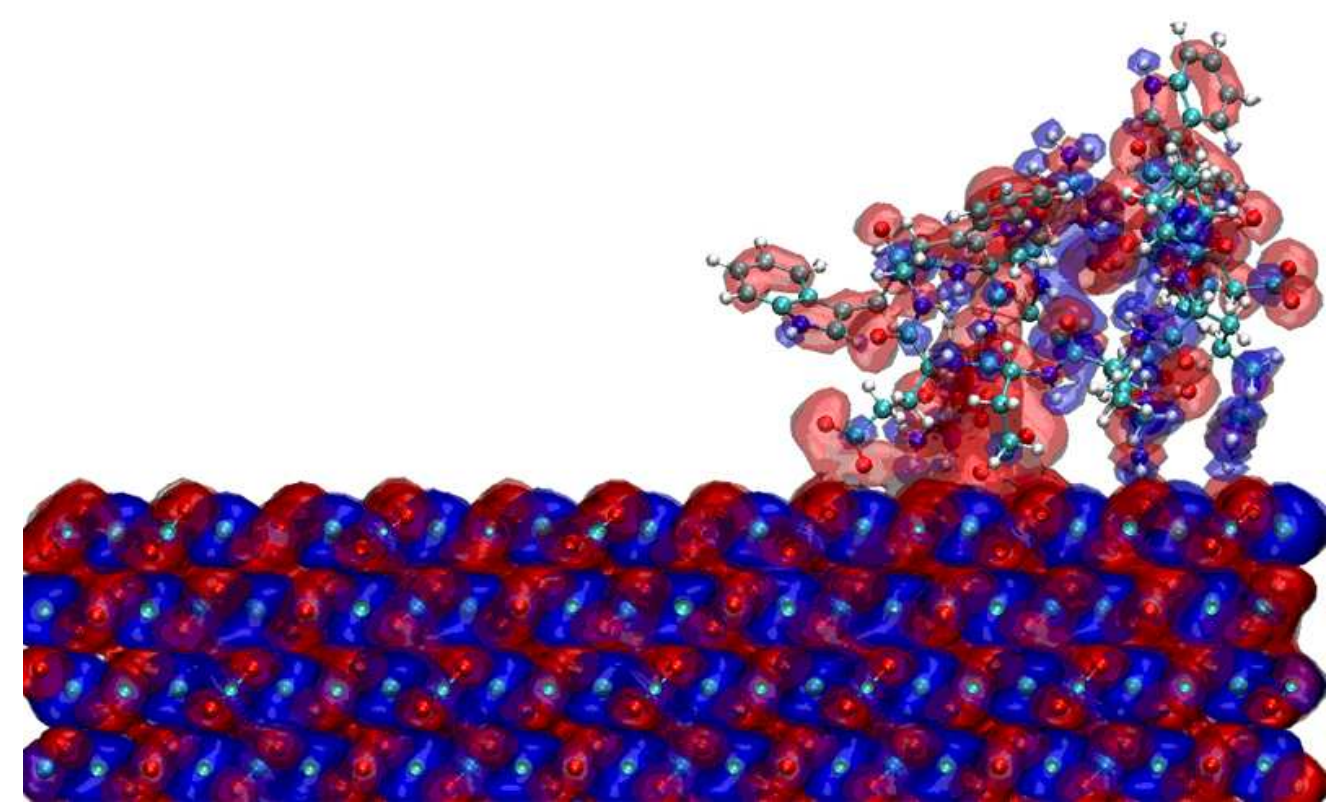

$67 \times 41 \mathrm{~mm}(300 \times 300$ DPI $)$

http://mc.manuscriptcentral.com/tandf/jenmol 


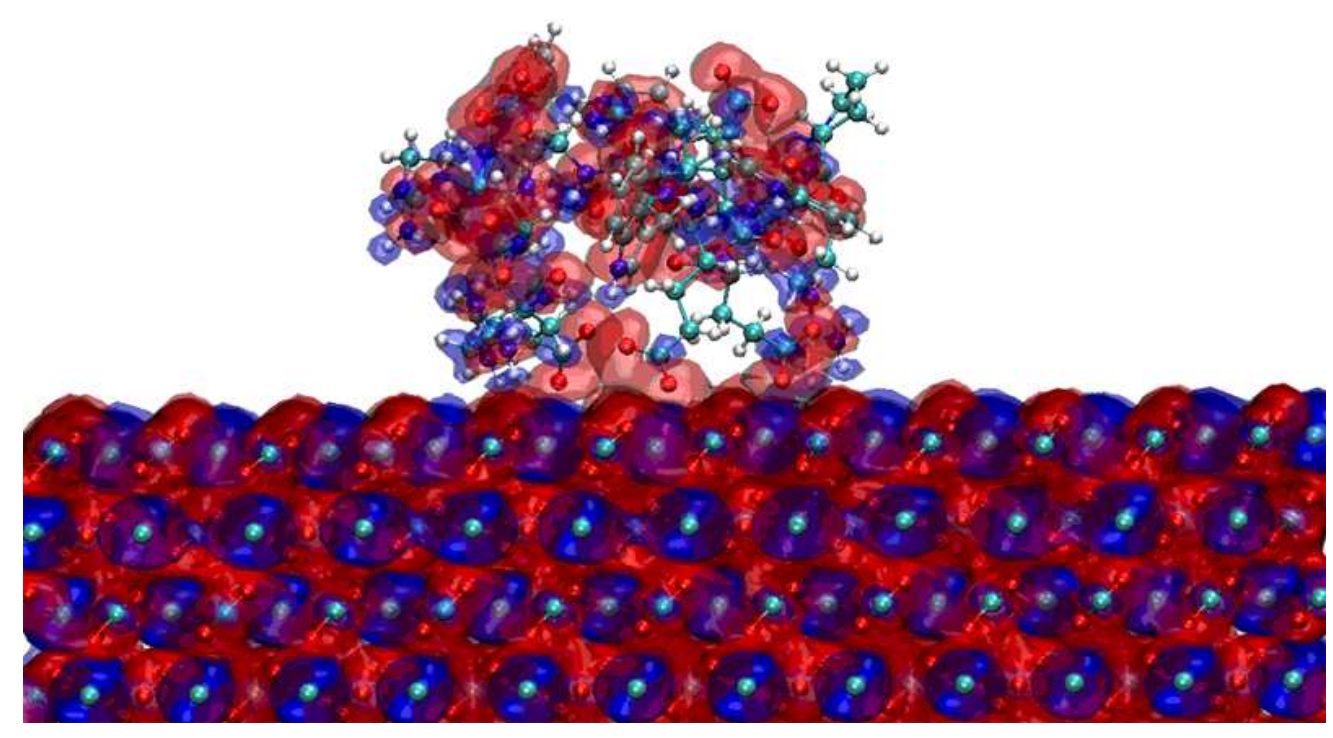

$67 \times 37 \mathrm{~mm}(300 \times 300$ DPI $)$

1
2
3
4
5
6
7
8
9
10
11
12
13
14
15
16
17
18
19
20
21
22
23
24
25
26
27
28
29
30
31
32
33
34
35
36
37
38
39
40
41
42
43
44
45
46
47
48
49
50
51
52
53
54
55
56
57
58
59
60




\section{Page 41 of 41}

1
2
3
4
5
6
7
8
9
10
11
12
13
14
15
16
17
18
19
20
21
22
23
24
25
26
27
28
29
30
31
32
33
34
35
36
37
38
39
40
41
42
43
44
45
46
47
50
58
59
50
52
53
50

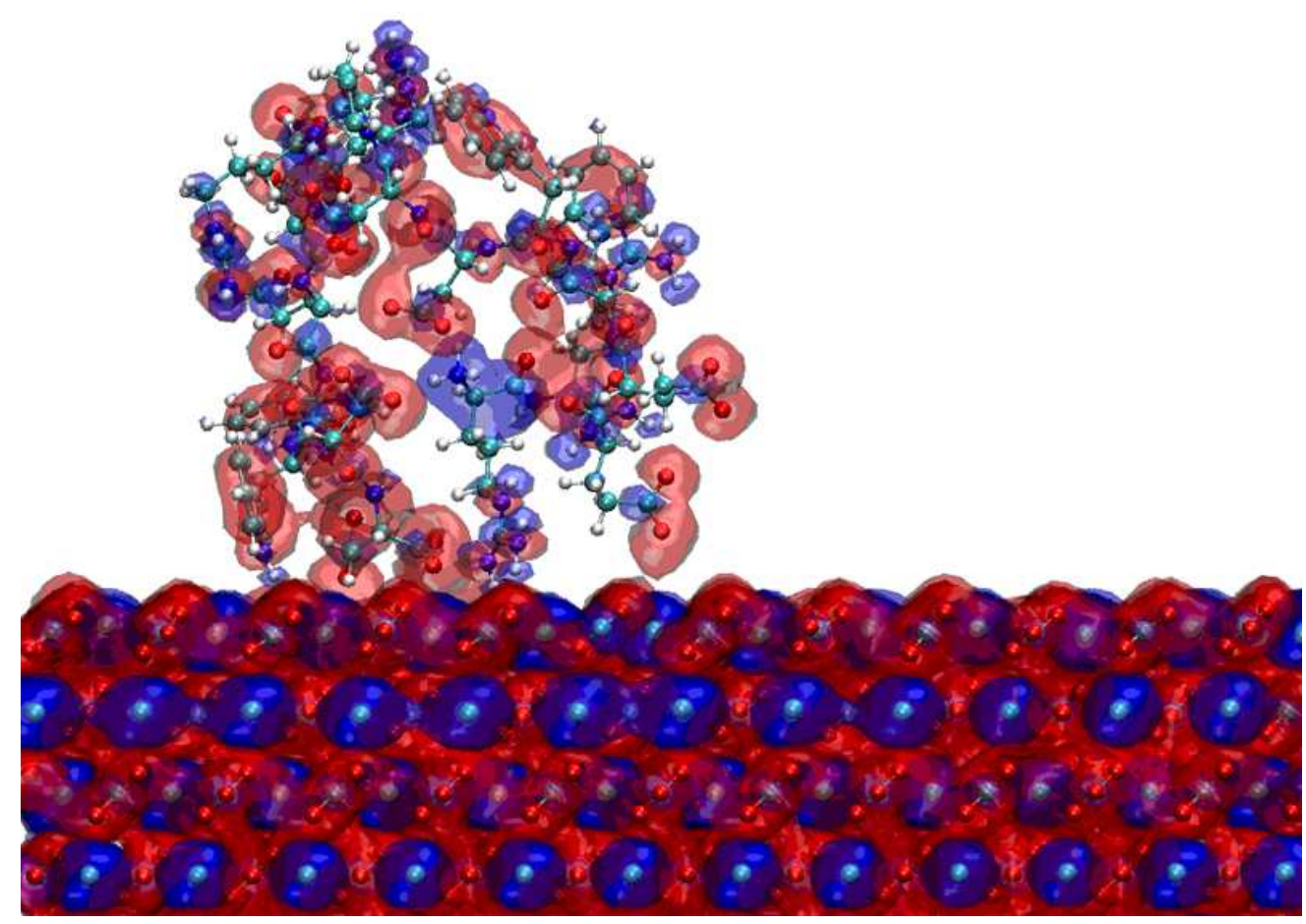

$67 \times 47 \mathrm{~mm}(300 \times 300 \mathrm{DPI})$

35

36

37
38

39

40

41

42

44

45

46

47

48

49

51

52

53

54

55

56

57
58

59

60

http://mc.manuscriptcentral.com/tandf/jenmol 